\title{
PERMIT REQUIREMENTS FOR DEVELOPMENT OF ENERGY AND OTHER SELECTED NATURAL RESOURCES FOR THE STATE OF MINNESOTA
}

\author{
PREPARED FOR \\ FOUR CORNERS REGIONAL COMMISSION \\ AND THE \\ U.S. GEOLOGICAL SURVEY \\ BY CAMP DRESSER AND MCKEE, INC.
}

Statements of opinion and/or recommendations are those of the authors and do not necessarily reflect the official opinion of the Four corners Regional Commission, any of its members States, or the U.S. Geological Survey. 


\title{
ACKNOWLEDGMENTS
}

The Minnesota guidebook was prepared under the direction of the U.S. Geological Survey (USGS) in cooperation with the Upper Great Lakes Regional Commission and the state of Minnesota. Funding support for this project was provided by the USGS Environmental Affairs office (EAO). Wilbert J. Ulman and James Frederick of the USGS Resource Planning and Analysis Office (RPAO) served respectively as Program Manager and Project Coordinator during the preparation of the guidebook. Both the RPAO and EAO are under the Office of Earth Sciences Applications (OESA). Gary Harms, Acting Executive Director of the Upper Great Lakes Regional Commission, acted as Project Manager. Ernie Petersen, the Minnesota Project Administrator for the Upper Great Lakes Regional Commission served as State Representative and provided valuable technical assistance. Camp Dresser and McKee, Inc. (CDM), of Wheat Ridge, Colorado, was responsible for compiling all available information and producing the final document. Margaret Colbert acted as Project Manager and Mary w. Vitter as Project Coordinator while the guidebook was prepared at CDM.

Request for information concerning this publication should be directed to either:

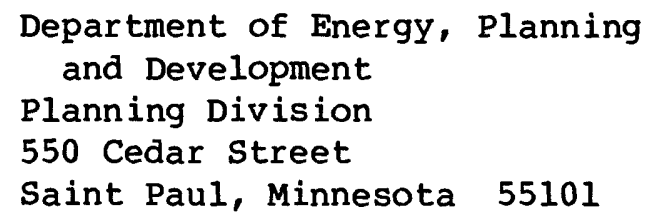

\author{
U.S. Geological Survey \\ Environmental Affairs office \\ 760 National Center \\ Reston, Virginia 22092
}

\section{PUBLICATION AVAILABILITY}

This Minnesota Permit Guide is available as an USGS Open-File Report \#81-1264 from:

\author{
U.S. Geological Survey \\ Open-File Services Section \\ Branch of Distribution \\ Denver Federal Center \\ Box 25425 \\ Denver, Colorado 80225
}


STATE PERMIT REQUIREMENTS FOR DEVELOPMENT OF ENERGY AND OTHER SELECTED NATURAL RESOURCES

STATE PERMIT GUIDES WILL BE AVAILABLE BY JANUARY 1982 FROM, USGS OPEN-FILE SERVICES SECTION, BRANCH OF DISTRIBUTION, BOX 25425, DENVER, COLORADO 80225

\begin{tabular}{|c|c|c|c|}
\hline state & Open File\# & State & Open File : \\
\hline Alabama & $81-1248$ & Nebraska & $81-1268$ \\
\hline Alaska & $81-1249$ & New Mexico & $81-1269$ \\
\hline Arizona & $81-1250$ & New York & $81-1270$ \\
\hline Arkansas & $81-1251$ & Nevada & $81-1271$ \\
\hline California & $81-1252$ & North Carolina & $81-1272$ \\
\hline Colorado & $81-1253$ & North Dakota & $81-1273$ \\
\hline Florida & $81-1254$ & Ohio & $81-1274$ \\
\hline Georgia & $81-1255$ & Oklahoma & $81-1275$ \\
\hline Idaho & $81-1256$ & Oregon & $81-1276$ \\
\hline Illinois & $81-1257$ & Pennsylvania & $81-1277$ \\
\hline Indiana & $81-1258$ & South Carolina & $81-1278$ \\
\hline Ransas & $81-1259$ & South Dakota & $81-1279$ \\
\hline Rentucky & $81-1260$ & Tennessee & $81-1280$ \\
\hline Iouisiana & $81-1261$ & Texas & $81-1281$ \\
\hline Maryland & $81-1262$ & Utah & $81-1282$ \\
\hline Michigan & $81-1263$ & Virginia & $81-1283$ \\
\hline Minnesota & $81-1264$ & Washington & $81-1284$ \\
\hline Missouri & $81-1265$ & West Virginia & $81-1285$ \\
\hline Mississippi & $81-1266$ & Wisconsin & $81-1286$ \\
\hline Montana & $81-1267$ & Wyoming & $81-1287$ \\
\hline
\end{tabular}


TABLE OF CONTENTS

Section

Page

ACKNOWLEDGMENTS

1.0 INTRODUCTION.

2.0 STATE POLICY AND PROCEDURES FOR CONSOLIDATED PERMIT PROGRAM

2.1 STATE CLEARINGHOUSE OR ONE-STEP PERMIT AGENCY........ 4

2.2 STATE EQUIVALENT OF NEPA..................... 5

3.0 RESOURCE EXTRACTION

3.1 PERMIT FOR RE-INJECTION OF WATER (HEAT PUMP PERMIT) .... 6

3.2 REGISTRATION FOR DRILLING OF MONITORING WELLS......... 8

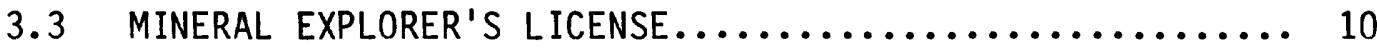

3.4 LICENSE FOR PETROLEUM PRODUCTS DISTRIBUTORS ........... 12

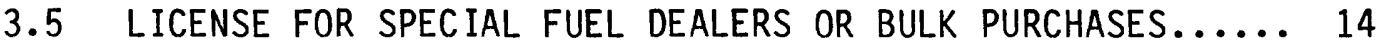

3.6 PERMIT FOR TRANSPORTATION OF PETROLEUM PRODUCTS ........ 16

3.7 PERMIT FOR POSSESSION AND USE OF EXPLOSIVES $\ldots \ldots \ldots \ldots \ldots \ldots$.

3.8 LICENSE FOR MANUFACTURE AND STORAGE OF EXPLOSIVES ...... 20

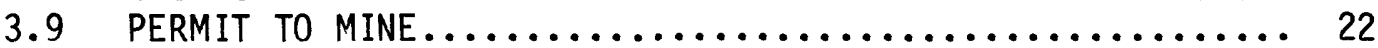

3.10 REGISTRATION OF EXPLORERS ..................... 25

3.11 IRON ORE PROSPECTING PERMT AND MINING LEASE, TACONITE IRON ORE PROSPECTING PERMIT AND MINING LEASE PUBLIC SALE............................... 27

3.12 IRON ORE MINING LEASE OR TACONITE IRON ORE MINING LEASE - NEGOT IATED .......................... 31

3.13 STOCKPILED IRON ORE PROSPECTING PERMIT AND MINING LEASE, STOCKP ILED TACONITE IRON ORE PROSPECTING PERMIT AND MINING LEASE........................... 34

3.14 PERMIT TO PROSPECT FOR AND LEASES TO MINE COPPER, NICKEL, AND ASSOC IATED MINERALS .............. 37

3.15 LEASE FOR REMOVAL OF STOCKPILED IRON-BEARING MATERIAL ... 41

3.16 HORTICULTURAL OR AGRICULTURAL PEAT LEASE............ 43

3.17 APPROVAL TO MINE UNDER PUBLIC WATERS............... 44

3.18 PERMIT FOR PROSPECTING FOR IRON ORE IN THE BEDS OF STATE WATERS ........................... 46

3.19 PERMIT FOR PROSPECTING FOR MINERALS UNDER WATERS OF LAKES AND STREAMS ........................ 49

3.20 LICENSE TO DEPOSIT TAILINGS FROM IRON ORE IN ANY PUBLIC LAKE.............................. 52

3.21 PERMIT FOR DRAINAGE OR DIVERSION TO FACILITATE MINING... 55

4.0 LAND USE REGULATIONS

4.1 ROUTING HIGH-VOLTAGE TRANSMISSION LINES AND SITING LARGE ELECTRIC POWER GENERATING PLANTS PERMITS ......... 59

4.2 CERTIF ICATE OF SITE COMPATIBIL ITY ................. 63

4.3 ABANDONED PROPERTY SEARCH AND/OR DISPOSITION PERMIT..... 66

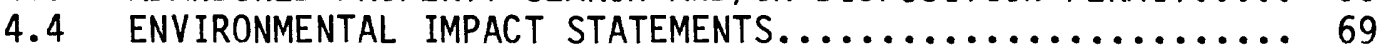

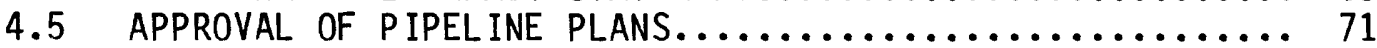

4.6 PERMIT FOR UTILITY CROSSINGS OF PUBLIC LANDS

AND WATERS ............................. 73 
TABLE OF CONTENTS (continued)

Section

4.7 LEASE ALLOWING USE OF STATE LANDS FOR TACONITE MINING... 75

4.8 LEASE ALLOWING USE OF STATE LANDS FOR ACTIVITIES

RELATED TO COPPER AND NICKEL MINING............... 77

4.9 CERT IF ICATE OF NEED FOR CONSTRUCTION OF LARGE ENERGY

FAC ILITIES .................................. 79

4.10 RIGHT-OF-WAY AND LIMITED LAND USE PERMIT $\ldots \ldots \ldots \ldots \ldots \ldots, 82$

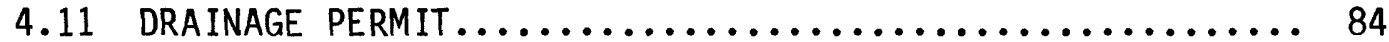

4.12 ACCESS DRIVEWAY PERMIT $\ldots \ldots \ldots \ldots \ldots \ldots \ldots \ldots \ldots \ldots \ldots, 86$

5.0 ENVIRONMENTAL QUALITY MANAGEMENT

5.1 PERMIT TO CHANGE THE COURSE, CURRENT, OR CROSS SECTION

OF PUBLIC WATERS................................... 88

5.2 PERMIT FOR APPROPRIATION OF WATERS OF THE STATE OF

MINNESOTA................................... 91

5.3 PERMIT FOR DISPLACEMENT OF UNDERGROUND WATERS BY

UNDERGROUND STORAGE OF GAS OR LIQUID UNDER PRESSURE

AND/OR STORAGE OF GAS OR LIQUID UNDERGROUND IN NATURAL

FORMATIONS.................................... 94

5.4 APPROVAL OF PLANS FOR CONSTRUCTION OR ALTERATION OF

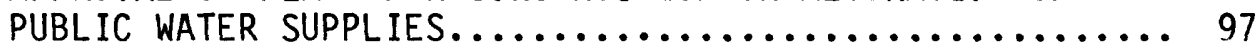

5.5 WATER WELL CONTRACTOR'S LICENSE................. 99

5.6 LICENSE FOR LIFE-SUPPORT TRANSPORTATION SERVICES........ 102

5.7 PERMIT FOR THE CONSTRUCTION OR OPERATION OF A HAZARDOUSWASTE FACILITY................................ 104

5.8 PERMIT FOR CONSTRUCTION OR OPERATION OF A SOLID-WASTEDISPOSAL FACILITY.............................. 107

5.9 AIR QUALITY INSTALLATION PERMIT................. 109

5.10 AIR QUALITY OPERATING PERMIT $\ldots \ldots \ldots \ldots \ldots \ldots \ldots \ldots \ldots \ldots, 111$

5.11 INDIRECT SOURCE PERMIT $\ldots \ldots \ldots \ldots \ldots \ldots \ldots \ldots \ldots \ldots \ldots \ldots, 113$

5.12 OPEN BURNING PERMIT ........................... 115

5.13 DISEASED SHADE TREE OPEN BURNING SITE PERMIT $\ldots \ldots \ldots \ldots \ldots, 118$

5.14 CERTIF ICATE OF EXEMPTION FOR PCB $\ldots \ldots \ldots \ldots \ldots \ldots \ldots \ldots \ldots, 121$

5.15 PERMIT FOR LIQUID STORAGE SITE................... 123

5.16 NPDES AND STATE DISPOSAL PERMIT ................... 125

5.17 STATE CERTIF ICATION FOR FEDERAL PERMITS UNDER THE

1977 CLEAN WATER ACT............................ 128

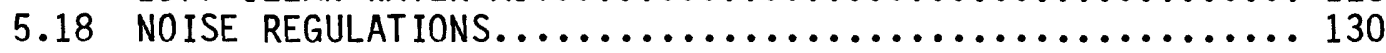

6.0 SOCIAL/ECOLOGICAL PRESERVATION

6.1 WILDLIFE COLLECTION PERMITS....................... 131

6.2 HISTORICAL PRESERVATION $\ldots \ldots \ldots \ldots \ldots \ldots \ldots \ldots \ldots \ldots \ldots \ldots, 132$

7.0 LOCAL REGULATORY POLICY

7.1 LOCAL GOVERNMENT LAND USE AND NATURAL RESOURCE

CONTROL ENABLING LAWS.......................... 133 
SECTION 1.0

INTRODUCTION 


\section{INTRODUCTION}

This guidebook is one of a series prepared for numerous States. The purpose of the guidebook is to summarize environmental and landuse permits issued by the State for the development of energy and other natural resources. The guidebook is intended not only for private developers and interest groups, but also for regulatory officials of Federal, State, and local government as we11. THIS GUIDEBOOK INCLUDES STATE ISSUED PERMITS ONLY, AND DOES NOT INCLUDE FEDERAL PERMITS.

All State agencies having jurisdiction over the permits, licenses, and approvals described in this guidebook helped to prepare it, and they reviewed the final draft of each summary for accuracy and completeness. Users of this guidebook should be aware, however, that changes in the laws, rules and regulations, or regulatory personnel since the guidebook was published may cause significant changes in permit requirements.

The guidebook should not be construed as a legal document or a final authority on permits for the State of Minnesota; it is not intended to be a comprehensive reference to the specific requirements of each permit, but to provide concise, easy-to-use information on the State regulations that govern the development of such resources. Before attempting to obtain a permit or begin any activity that might require a permit, you should contact the appropriate State agency for further details.

The guidebook is divided into seven sections. Sections 1.0, 2.0, and 7.0 discuss introductory information, consolidated permit programs for the State of Minnesota, and local regulatory policies, respectively. The remaining sections discuss permits that apply to Resource Extraction, Land Use Regulation, Environmental Quality Management, and Social/Ecological Preservation. Each section is divided into chapters; each chapter summarizes one permit, license, or approval. Permits administered by a single agency are generally grouped together in each section.

Each permit is discussed in the standard format shown on pages 2 and 3. 
CHAPTER 0.0

TITLE OF ACTIVITY ADDRESSED BY PERMIT, LICENSE, OR APPROVAL

INTRODUCTION

Description of administering agency and its role

A. NAME OF PERMIT OR APPROVAL:

Complete name of permit or approval with notation indicating mandate by State (S) or Federal (F) government

B. STATUTORY AUTHORITY:

Title of State statutes authorizing permit and the legal citations of each with notation indicating pending changes $(P)$ to the statute(s)

C. TITLE OF REGULATION:

Title of State regulation(s) which apply to permit with notation indicating pending changes $(P)$ to the regulation(s)

D. SUMMARY OF PERMIT/APPROVAL PROCESS:

Summary of major steps involved in the permit/approval process

1. Applicability

Includes all types of activities which require the permit

2. General Requirements

Conditions which must be met by the project sponsor before a permit can be acquired; excluding Submissions or Operations Requirements

3. Submission Requirements

Types of information which the project sponsor must include in the application for the permit 


\section{CHAPTER 0.0 (continued)}

4. Procedures for Obtaining Permit or Approval

Includes information on items such as submittal procedures, completeness and technical review, public notice, comment and

hearing periods, preliminary and final decisions, inspections, and processing times

5. Operations Requirements

Conditions which are established by the regulatory agency following permit approval and which must be met by the project sponsor in order to continue operations

6. Fees

Costs incurred for obtaining and maintaining the permit

\section{Appeal Process}

Process whereby decisions concerning permit approval/denial that are made by a regulatory agency can be appealed

\section{E. ADMINISTERING AGENCY:}

Name of the administering agency and its director, address, and telephone number

Name of the counterpart Federal agency and its director, address, and telephone number 


\section{SECTION 2.0 \\ STATE POLICY AND PROCEDURES \\ FOR CONSOL IDATED PERMIT PROGRAM}




\section{STATE CLEARINGHOUSE OR ONE-STEP PERMIT AGENCY}

The Minnesota Legislature passed the "Environmental Coordination Procedures Act" in 1976. This law provides for a new State permit application procedure called the "Master Application Process," and establishes information centers called Environmental Management information centers (EMIC's) to aid in the understanding of State permit requirements.

The Master Application Process is for projects affecting the natural environment and is a way for obtaining all necessary State permits by routing through one office. EMIC's have information about permit requirements and application procedures, as well as grant programs and environmental management services administered by the government. These services are provided by the permit Coordination Unit of the Minnesota Environmental Quality Board.

For more information call:

Within the Metropolitan Area 296-8541

Outside the Metropolitan Area call collect (612) 296-9034

Branch EMIC's are located in the following Regional Development Commission offices:

Region 1

425 Woodland Avenue

Crookston, MN 56716

218/281-1396

Region 4

Administration Bldg.

Fergus Falls Comm. College

Fergus Falls, MN 56537

218/739-3356

Region $6 \mathrm{~W}$

323 West Schlieman

Appleton, MN 56208

612/289-1981

Region 8

Peoples State Bank

25th and Broadway

S1ayton, MN 56172

612/253-7870
Region 2

Mental Health Building

Box 584

Bemidjii, MN 56601

218/751-3108

Region 5

102 6th Street North

Staple, MN 56479

218/894-3233

Region $7 E$

Kanabec Cnty. Courthouse

18 North Vine Street

Minnesota

612/679-4065

Region 9

120 South Broad Street

(01d Library Building)

Mankato, MN 56001

507/285-2550
Region 3

200 Arrowhead Place

211 West Second Street

Duluth, MN 55802

218/722-5545

Region 6E

City Auditorium

311 West 6 th Street

Willmar, MN 56201

612/253-8504

Region $7 W$

2700 1st Street North

Saint Cloud, MN 56301

612/253-7870 


\section{STATE EQUIVALENT OF NEPA}

Minnesota has a State equivalent of the National Environmental Policy Act (NEPA), the Minnesota Environmental Policy Act (MEPA).

MEPA, adopted in 1973, applies to any activity which "...has, or is likely to pollute, impair or destroy the air, water or other natural resources or the public trust therein..." An action may be defended by demonstrating that "...there is no feasible and prudent alternative..." and that the action is "...consistent with the promotion of the public health, safety and welfare in light of the State's paramount concern for the protection of its natural resources from pollution, impairment or destruction."

MEPA suits can be filed by any person, organization, government body or other legal entity. MEPA is supplemental to all other Minnesota environmental 1aws. 
SECTION 3.0

RESOURCE EXTRACTION

$5 a$ 


\section{PERMIT FOR RE-INJECTION OF WATER (HEAT PUMP PERMIT)}

\section{INTRODUCT ION}

The Water Supply and General Engineering Section, within the Minnesota Department of Health $(M D H)$, has responsibility for issuing permits for re-injection of water, under the authority of Minnesota Laws 1981, Chapter 179. Any person who proposes to install a ground-water heat pump must first obtain a permit to re-inject water into the aquifer from which it was drawn.

A. NAME OF PERMIT OR APPROVAL:

- Permit for Re-Injection of Water (Heat Pump Permit) (S)

B. STATUTORY AUTHORITY:

- Minnesota Laws 1981, Chapter 179, Sections 2 through 4

C. TITLE OF REGULATION:

- Minnesota Code of Agency Rules, Title 7, Sections 1.217 through 1.224

D. SUMMARY OF PERMIT/APPROVAL PROCESS:

1. Applicability

- A person may not operate a ground-water heat pump without obtaining a permit to re-inject water

2. General Requirements

- Applicant must submit a completed application on a prescribed form

3. Submission Requirements

- Plans and specifications must show

- Proposed location and construction of well(s) and compliance with the well code

- Compliance with legal requirement that the system be completely closed and that provision be made for sampling water quality and temperature in the well(s) 
4. Procedure for Obtaining Permit or Approval

- Applicant submits application to $\mathrm{MDH}$

- Once the application is submitted to MDH, it is reviewed for completeness and conformance to the requirements of the law and well code

- Permit is issued

- No formal procedures or prescribed time limits for processing

5. Operations Requirements

- The permittee must comply with all the general and special conditions prescribed in the permit

6. Fees

- Initial permit - $\$ 50$

7. Appea1 Process

- None has been established, although an applicant could request a contested case hearing as provided for in the Administrative Procedures Act (Minnesota Statutes, Section 15.0418 (1980)

E. ADMINISTERING AGENCY:

Chief

Water Supply and General Engineering Section

Minnesota Department of Health

717 De1aware Street, Southeast

Minneapol is, Minnesota 55440

(612) 296-5330 
CHAPTER 3.2

\section{REGISTRATION FOR DRILLING OF MONITORING WELLS}

INTRODUCTION

The Water Supply and General Engineering Section, within the Minnesota Department of Health $(\mathrm{MDH})$, has responsibility for registering engineers who dri11 monitoring wel1s, under the authority of Minnesota Laws 1981, Chapter 179. The purpose of this registration is to ensure proper drilling of monitoring we11s.

A. NAME OF PERMIT OR APPROVAL:

- Registration for Drilling of Monitoring Wells (S)

B. STATUTORY AUTHORITY:

- Minnesota Laws 1981, Chapter 179, Section 1, amending Minnesota Statutes, Section 156A.03 (1980)

C. TITLE OF REGULATION:

- Rule pending as of 23 September 1981

D. SUMMARY OF PERMIT/APPROVAL PROCESS:

- Process pending as of 23 September 1981

1. Applicability

- Civil and geological engineers, registered by the State of Minnesota as professional engineers, who wish to construct monitor wells (as defined in rule)

2. General Requirements

- An applicant must complete a form prescribed by MDH and pay fees to be prescribed in rules which are yet to be adopted 
- Civil or geological engineers registered in Minnesota, who drill monitoring wells, need only register with the Commissioner of Health but need not be 1 icensed as water well contractors

- Annual registration is required

3. Submission Requirements

- The application form is not complete as of 19 August 1981

- Personal information about the applicant and professional engineer's registration number will be required

4. Procedures for Obtaining Permit or Approval

- Registration will be effective merely by filing the completed form and payment of a $\$ 50$ annual registration fee

5. Operations Requirements

- The registrant must comply with all applicable rules and regulations for monitoring

6. Fees

- Annual registration - $\$ 50$

7. Appeal Process

- None

E. ADMINISTERING AGENCY:

Chief

Water Supply and General Engineering Section

Minnesota Department of Health

717 Delaware Street, Southeast

Minneapolis, Minnesota 55440

(612) 296-5330 
CHAPTER 3.3

MINERAL EXPLORER'S LICENSE

INTRODUCTION

The Water Supply and General Engineering Section, within the Minnesota Department of Health (MDH), has responsibility for issuing licenses for mineral explorers under the authority of Minnesota Statutes, Chapter 156A. The purpose of this license is to regulate mineral exploration.

A. NAME OF PERMIT OR APPROVAL:

- Mineral Explorer's License (S)

B. STATUTORY AUTHORITY:

- Minnesota Statutes, Sections 156A.02, 156A.04, and 156A.071

C. TITLE OF REGULATION:

- Minnesota Code of Agency Rules, Title 7, Section 1.225

D. SUMMARY OF PERMIT/APPROVAL PROCESS:

1. Applicability

- Any exploratory surface drilling for oil, natural gas, and metallic minerals (except natural iron ore)

2. General Requirements

- Applicant must obtain a right to explore and pass an examination, unless the person is a professional engineer or certified professional geologist

- A person who oversees exploration for minerals (except natural iron ore) must first obtain a license from the Cormissioner of Health.

- Applicant must pay fees prescribed in rule 
3. Submission Requirements

- Names and personal information of all persons who are designated and authorized to do fieldwork for the applicant

4. Procedures for Obtaining Permit or Approval

- Applicant submits completed application on a prescribed form to MDH for review

- If the application is complete, an examination on relevant portions of the rule is given by the MDH staff

- Applicant may be interviewed by an advisory council which al so reviews the application and then makes a recommendation to the Commissioner of Health as to whether a license should be issued

- No prescribed time limits for processing the applicant

5. Operations Requirements

- The licensee must comply with all rules and regulations and any stipulations set forth within the licensing procedures

6. Fees

- Application - $\$ 50$

- Annual license - $\$ 50$

7. Appeal Process

- The Minnesota Administrative Procedures Act provides for requesting a contested case hearing (Minnesota Statutes, Section $15.0418(1980)$ )

\section{E. ADMINISTERING AGENCY:}

Chief

Water Supply and General Engineering Section

Minnesota Department of Health

717 Delaware Street, Southeast

Minneapolis, Minnesota 55440

(612) 296-5330 
CHAPTER 3.4

\section{LICENSE FOR PETROLEUM PRODUCTS DISTRIBUTORS}

INTRODUCTION

The Minnesota Department of Revenue (MDR) has responsibility for issuing licenses for petroleum products distributors, under the authority of Minnesota Statutes, Chapter 296. The purpose of this permit is to ensure that petroleum products are distributed in accordance with rules and regulations set forth by the State.

A. NAME OF PERMIT OR APPROVAL:

- License for Petroleum Products Distributors (S)

B. STATUTORY AUTHORITY:

- Minnesota Statutes, Section 296.06

C. TITLE OF REGULATION:

- Minnesota Code of Agency Rules for Gas Tax, Title 13, Chapter 10

D. SUMMARY OF PERMIT/APPROVAL PROCESS:

1. Applicability

- Receiving gasoline or fuel oil in Minnesota for further distribution

- Receiving petroleum products in Minnesota for storage and subsequent distribution by tank car or tank truck

- Producing, manufacturing, or refining petroleum products

- Importing petroleum products into Minnesota by boat, barge, or pipeline for storage and subsequent delivery

- Holding a license and performing as a distributor in an adjoining State

2. General Requirements

- This permit must be obtained prior to engaging in any of the above activities 


\section{Submission Requirements}

- Applicant must submit a completed license application form supplied by the State and a current financial statement

4. Procedures for Obtaining Permit or Approval

- Applicant submits application to MDR, Petroleum Division

- MDR reviews application for completeness

- MDR determines if financial statement is adequate when compared to anticipated liabilities

- Upon approval, license with identifying number is mailed to applicant

- Total estimated processing time, 10 working days

5. Operations Requirements

- Licensee must maintain proper records, file tax returns, and remit taxes when due

6. Fees

- $\$ 5$

7. Appeal Process

- Applicant may reapply if license is denied provided that further information is submitted to meet qualifications

E. ADMINISTERING AGENCY:

Minnesota Department of Revenue

Centennial office Building

658 Cedar Street

Saint Paul, Minnesota 55145

(612) 296-3401 
CHAPTER 3.5

LICENSE FOR SPECIAL FUEL DEALERS OR BULK PURCHASES

INTRODUCTION

The Minnesota Department of Revenue (MDR) has responsibility for issuing licenses for special fuel dealers or bulk purchases, under the authority of Minnesota Statutes, Chapter 296. The purpose of this license is to ensure that the sale and bulk purchase of special fuel are in accordance with rules and regulations set forth by the State.

A. NAME OF PERMIT OR APPROVAL:

- License for Special Fuel Dealers or Bulk Purchases (S)

B. STATUTORY AUTHORITY:

- Minnesota Statutes, Section 296.12

C. TITLE OF REGULATION:

- Minnesota Code of Agency Rules for Gas Tax, Title 13, Chapter 6

D. SUMMARY OF PERMIT/APPROVAL PROCESS:

1. Applicability

- Any person wishing to sell special fuel, or purchase special fuel in bulk for own use

2. General Requirements

- Applicant must propose to be in business of selling motor fuel or storing special fuel for own use

3. Submission Requirements

- Completed license application

- Current financial statement

4. Procedures for Obtaining Permit or Approval

- Applicant submits a completed application to MDR, Petroleum Division 
- MDR determines if financial statement is adequate when compared to anticipated liabilities

- Upon approval, license with identifying number is mailed to applicant

- Total estimated processing time, 10 working days

5. Operations Requirements

- Licensee must maintain proper records, file tax returns, and remit taxes when due

6. Fees

- $\$ 5$

7. Appeal Process

- Applicant may reapply if license is denied provided that further information is submitted to meet qualifications

E. ADMINISTERING AGENCY:

Minnesota Department of Revenue

Centennial office Building

658 Cedar Street

Saint Paul, Minnesota 55145

(612) 296-3401 


\section{INTRODUCTION}

The Minnesota Department of Revenue (MDR) has responsibility for issuing permits for transportation of petroleum products, under the authority of Minnesota Statutes, Chapter 296. The purpose of this permit is to regulate the transport of petroleum.

A. NAME OF PERMIT OR APPROVAL:

- Permit for Transportation of Petroleum Products (S)

B. STATUTORY AUTHORITY:

- Minnesota Statutes, Section 296.10

C. TITLE OF REGULATION:

- Minnesota Code of Agency Rules for Gas Tax, Title 13, Chapter $2(b)(c)(d)$

D. SUMMARY OF PERMIT/APPROVAL PROCESS:

1. Applicability

- Any person transporting petroleum products in Minnesota in truck transports having a cargo-tank capacity in excess of 2,100 gallons

2. General Requirements

- Permit number must be displayed on left front and right rear of cargo tank

3. Submission Requirements

- Completed application including tank capacity and manufacturer's tank serial number 
4. Procedures for Obtaining Permit or Approva1

- Applicant submits application to MDR, Petroleum Division

- MDR reviews application for completeness

- Upon approval, permit with identifying number is mailed to applicant

5. Operations Requirements

- Permittee must properly identify cargo tank with assigned number

6. Fees

- None

7. Appeal Process

- Applicant may reapply if license is denied provided that information is submitted to meet qualifications

E. ADMINISTERING AGENCY :

Minnesota Department of Revenue

Centennial office Building

658 Cedar Street

Saint Paut, Minnesota 55145

(612) 296-3401 


\section{PERMIT FOR POSSESSION AND USE OF EXPLOSIVES}

\section{INTRODUCTION}

The Bureau of Criminal Apprehension, within the Minnesota Department of Public Safety (MDPS), has responsibility for issuing permits for the possession and use of explosives, under the authority of Minnesota Statutes, Chapter 299. The purpose of this permit is to ensure that the possession and use of explosives are in accordance with the rules and regulations set forth by the State.

A. NAME OF PERMIT OR APPROVAL:

- Permit for Possession and Use of Explosives (S)

B. STATUTORY AUTHORITY:

- Minnesota Statutes, Section 299F.74

C. TITLE OF REGULATION:

- Minnesota Code of Agency Rules, Title 11, Sections 1.3001 through 1.3049

D. SUMMARY OF PERMIT/APPROVAL PROCESS:

1. Applicability

- Possession and use of explosives

2. General Requirements

- Application form BCA 04039 must be completed

- Federally approved storage containers must be used if explosives are not used immediately

3. Submission Requirements

- Purpose for acquiring explosives

- Place of intended acquisition

- Quantity required 
- Time and place of intended use

- $\quad$ Place and means of storage

- Information to determine whether the applicant is prohibited from being issued a license according to statutes

4. Procedures for Obtaining Permit or Approval

- Applicant submits application to the appropriate local sheriff or chief of police or such other person who may be designated by the Commissioner of Public Safety

- Application is approved or denied by the Commissioner of Public Safety

5. Operations Requirements

- Following approval, the permit must comply with MDPS rules and regulations for the transportation, storage, and use of explosives and blasting agents

6. Fees

- State - None

- City or county - Variable

7. Appeal Process

- Any person aggrieved by the denial of a permit may request a hearing, and the contested case administrative hearing procedures of statute shall apply

E. ADMINISTERING AGENCY:

Commissioner

Bureau of Criminal Apprehension

Minnesota Department of Public Safety

1246 University Avenue

Saint Pau1, Minnesota 55104

(612) 296-6905 or (612) 296-7454 


\section{LICENSES FOR MANUFACTURE AND STORAGE OF EXPLOSIVES}

INTRODUCTION

The Bureau of Criminal Apprehension, within the Minnesota Department of Public Safety (MDPS), has responsibility for issuing licenses for manufacturing and storing explosives, under the authority of Minnesota Statutes, Chapter 299. The purpose of this permit is to ensure that the manufacture and storage of explosives are in accordance with the rules and regulations set forth by the State.

A. NAME OF PERMIT OR APPROVAL:

- Licenses for Manufacture and Storage of Explosives (S)

B. STATUTORY AUTHORITY:

- Minnesota Statutes, Section 299F.73

C. TITLE OF REGULATION:

- Minnesota Code of Agency Rules, Title 11, Sections 1.3001 through 1.3049

D. SUMMARY OF PERMIT/APPROVAL PROCESS:

1. Applicability

- Manufacturing, storing, or selling explosives in the wholesale or retail market

2. General Requirements

- Application form PS 40520 must be completed

3. Submission Requirements

- Age, experience, and knowledge of the applicant in the handling and storing of explosives

- Information to determine whether the applicant is prohibited from being issued a license according to statutes 
4. Procedures for Obtaining Permit or Approval

- Applicant submits application to MDPS, Bureau of Criminal Apprehension

- Tota1 estimated processing time, 10 working days

- Permit is either approved or denied by the Commissioner of Pub1ic Safety

5. Operations Requirements

- Following approval, the permittee must comply with MDPS rules and regulations for the transportation, manufacture, storage, and use of explosives and blasting agents

6. Fees

- None

7. Appeal Process

- Any person aggrieved by the denial of a 1 icense may request a hearing, and the contested case administrative hearing procedures of statute shall apply

E. ADMINISTERING AGENCY:

Commissioner

Bureau of Crimina1 Apprehension

Minnesota Department of Public Safety

1246 University Avenue

Saint Paul, Minnesota 55104

(612) 296-6905 or (612) 296-7454 
CHAPTER 3.9

PERMIT TO MINE

\section{INTRODUCTION}

The Division of Minerals within the Minnesota Department of Natural Resources (MDNR), has responsibility for issuing permits to mine, under the authority of Minnesota Statutes, Chapter 93. Legislation authorizes regulation of any metallic mining in the State. Rules have been adopted only for the mining of taconite and natural iron ore, since these activities occur in the State. Rules regulating the mining of copper, nickel, and associated minerals, and rules regulating bulk sampling of metallic minerals are currentiy being developed. No permits will be issued for mining operations from which the primary metal extracted is other than iron until rules regulating such operations have been adopted.

A. NAME OF PERMIT OR APPROVAL:

- Permit to Mine (S)

B. STATUTORY AUTHORITY:

- Minnesota Statutes, Sections 93.44 through 93.51

C. TITLE OF REGULATION:

- Minnesota Code of Agency Rules, Title 6, Chapters 1.0401 through 1.0407

D. SUMMARY OF PERMIT/APPROVAL PROCESS:

1. Applicability

- Any metallic mining in the State

2. General Requirements

- All new operations must obtain a mining permit or a scram mining permit before commencing operations

- Existing operations that were engaged in mining on the date of promulgation can continue to operate pending permit process

- All portions of new or reactivated operations and certain portions of operations existing prior to promulgation of the rules are subject to the requirements of the rules 
3. Submission Requirements

The operator must submit an application for a permit to mine which contains the following:

- Documents demonstrating financial capability, proof of insurance, and proof of authority to do business in Minnesota

- Organizational data identifying the structure and relationships of the operator

- Environmental setting maps

- Environmental analysis of the project and alternatives

- Mining and reclamation maps normally used by the operator for mine planning

- Mining and reclamation plan describing the operating life, the activities to be conducted, and the methods and sequence of reclamation

- Operating plan covering current or upcoming mining period

4. Procedures for Obtaining Permit or Approval

- Applicant submits application to MDNR, Division of Minerals

- Application is reviewed by various MDNR and/or other agencies, and field investigation is conducted

- Upon approval, operator must publish a description of the project in a newspaper circulated in the locality of the project, for 4 consecutive weeks

- If a valid objection is filed with the MDNR, a public hearing will be held; if no valid objections are filed, a public hearing is optional with commissioner and/or applicant

- If hearing is held, it must be held within 45 days of the receipt of the valid objections

- A determination must be made to grant or deny the permit within 120 days of the close of the hearing or 90 days after receiving the hearing examiner's report, whichever is later 
- If no objections are filed within 30 days of the last notice published, the commissioner may grant or deny the permit without a hearing within 120 days (This may be extended if additional information is required from the operator)

5. Operations Requirements

- The applicant must submit an operating plan for a period not to exceed 5 years

- The commissioner reviews the operating plan to determine compliance with the provisions of the permit

- An annual report must be submitted describing financial statements, rates of mining and the actual mining and reclamation activities pursued the previous year, including maps depicting the status of the operation

6. Fees

- None

7. Appeal Process

- The applicant may file with the commissioner a demand for hearing on the decision if the application is processed without a hearing

E. ADMINISTERING AGENCY:

Division of Minerals

Minnesota Department of Natural Resources

Box 45, Centennial Office Building

Saint Paul, Minnesota 55155

(612) 296-4807 


\section{REGISTRATION OF EXPLORERS}

\section{INTRODUCT ION}

The Division of Minerals, within the Minnesota Department of Natural Resources (MDNR), has responsibility for registering of explorers, under the authority of Minnesota Statutes, Chapter 156A. Any person proposing to conduct exploratory drilling in the State must be licensed by the Minnesota Department of Health and registered with MDNR.

A. NAME OF PERMIT OR APPROVAL:

- Registration of Explorers Engaged in Exploratory Boring (S)

B. STATUTORY AUTHORITY:

- Minnesota Statutes, Chapter 156A, as amended

C. TITLE OF REGULATION:

- None

D. SUMMARY OF PERMIT/APPROVAL PROCESS:

1. Applicability

- Any person proposing to construct exploratory borings for metallic minerals, oil, or natural gas

2. General Requirements

- At least 30 days before commencing exploratory boring, an explorer must be registered with MDNR

- The explorers must notify MDNR at least 10 days prior to drilling by submitting a county road map indicating the locations of the drill holes to the nearest 40 -acre parcel

3. Submission Requirements

- The registration form requests information on the exploration company and responsible parties 
4. Procedures for Obtaining Permit or Approval

- Applicant submits application to MDNR

- MDNR determines if a bond, security, or assurance of financial ability is required

- No public notice is required

- No set time is established; usually within 30 days of receipt of completed form, the decision is made

- Registration is for 1 year from date of approval

5. Operations Requirements

- The explorer must file with MDNR a copy of the abandonment report required under the rules of the Minnesota Department of Heal th

- The explorer must submit to MDNR all factual data and samples gathered during drilling no later than 6 months after termination of a public or private lease. (Such data must also be submitted when any State permit is required during mineral deposit evaluation activities (bulk sampling) or mine development)

- State statutes should be consulted regarding confidentiality of submitted data

6. Fees

- None

7. Appeal Process

- None

E. ADMINISTERING AGENCY:

Division of Minerals

Minnesota Department of Natural Resources

Box 45, Centennial Building

Saint Paul, Minnesota 55155

(612) 296-4807 
IRON ORE PROSPECTING PERMIT AND MINING LEASE, TACONITE IRON ORE PROSPECTING PERMIT AND MINING LEASE - PUBLIC SALE

\section{INTRODUCTION}

The Division of Minerals, within the Minnesota Department of Natural Resources (MDNR), has responsibility for issuing iron ore prospecting permits, under the authority of Minnesota Statutes, Chapter 93. The Commissioner of Natural Resources, with the approval of the State Executive Council, is authorized to issue permits for the purpose of prospecting for iron ore and leases for the mining of such ores from State-owned and Stateadministered 1 and.

A. NAME OF PERMIT OR APPROVAL:

- Iron Ore Prospecting and Mining Lease Taconite Iron Ore Prospecting Permit and Mining Lease - Public Sale (S)

B. STATUTORY AUTHORITY:

- Minnesota Statutes, Sections 93.14 through 93.24

C. TITLE OF REGULATION:

- None

D. SUMMARY OF PERMIT/APPROVAL PROCESS:

1. Applicability

- Prospecting for iron ore on State-owned and Stateadministered 1 and

2. General Requirements

- No permit for the same land is issued to the same person for 2 years in succession

- The work of prospecting under a permit begins in a substantial manner within 90 days from the date thereof and continues until the permit expires or is surrendered, or a lease is requested by the holder of a permit 
- The holder of a permit reports in writing to the commissioner the time of beginning prospecting, and thereafter on the first business day of each April, July, October, and January reports the the progress of the work of prospecting, and accompanies these reports with maps showing the character and extent of the work done, the nature of materials encountered in the work, and the analysis for iron, silica, phosphorus, alumina, and manganese of all iron-bearing formation encountered; provided that any hard rock or any taconite, as defined in Section 93.20, is encountered, the commissioner may require analytical information as he deems essential

- The permit holder splits all samples taken and furnishes the commissioner or his representative, from time to time as the commissioner or his representative directs, with a portion of the samples properly marked for identification

- Subject to the approval of the commissioner and under conditions as he may prescribe, a geophysical survey of the area may be accepted in lieu of drilling

- If the permittee elects to make a geophysical survey, upon completion he makes further exploration of the property as the commissioner may direct, and continues exploration until the permit expires or is surrendered, or an application is made for a lease

3. Submission Requirements

- For each mining unit, applicant submits

- Application on form obtained from MDNR

- Application Fee

- Bid on form obtained from MDNR and sealed in envelope obtained from MDNR

- Guarantee check, which is enclosed in sealed envelope with bid

4. Procedures for Obtaining Permit or Approval

- Applicant submits application to Commissioner of Natural Resources within time deadlines announced in public notice of sale

- Prospecting permits issued only on public sale (the sale of permits may be held annually, at the discretion of the commissioner, on the second Monday in August) 
- Commissioner gives public notice of each sale by publication for 4 successive weeks in a daily newspaper printed and published in each of the cities of Saint Paul, Minneapolis, Duluth, Hibbing, and Virginia (the last publication not less than 7 days nor more than 30 days before August 1 next preceding the sale)

- Permits awarded by commissioner with approval of executive council to highest bidder

- Bids must equal or exceed base rates specified in laws

- Right is reserved to reject any and all bids

- At any time prior to expiration of permit, if commissioner determines all terms and conditions of permit and applicable laws have been complied with, holder of permit has right to receive mining lease

- To receive lease, permit holder must file verified report on all exploration, or affidavit stating no exploration was done and pay rental for unexpired portion of first quarter of lease

5. Operations Requirements

- Work done by the permit holder is subject to inspection at all reasonable times by the commissioner or his representatives

- Every permit to prospect for ore is granted upon the express condition that if the permit holder fails to perform any of the terms, covenants, or conditions specified in the permit to be performed by him, then it is the duty of the commissioner to cancel the permit, first having mailed to the permit holder at least 20 days' notice in writing

6. Fees

- Prospecting permit:

- Application - $\$ 50$

- Guarantee check - $\$ 200$

- Mining lease:

- Annual rentals

- Iron ore - $\$ 1,250$ first year, $\$ 5,000 /$ yr thereafter 
CHAPTER 3.11 (concluded)

- Taconite - $\$ 400 / y r$ first 5 years, $\$ 1,600 / y r$ thereafter

- Royalties - minimum rates per ton of ore, as specified in laws, plus bid rates; total royalty rate subject to escalation

7. Appeal Process

- No special appeal process enacted; appeal would be to District Court

E. ADMINISTERING AGENCY:

Division of Minerals

Minnesota Department of Natural Resources

Box 45, Centennial Office Building

Saint Paul, Minnesota 55155

(612) 296-4807 
IRON ORE MINING LEASE OR TACONITE IRON ORE MINING LEASE - NEGOTIATED

\section{INTRODUCTION}

The Division of Minerals, within the Minnesota Department of Natural Resources (MDNR), has responsibility for issuing iron ore or taconite iron ore mining leases, under the authority of Minnesota Statutes, Chapter 94. The Commissioner of Natural Resources, with the approval of the State Executive Council, is authorized, under specific circumstances, to issue negotiated leases for the mining of iron ore from State-owned and State-administered land.

A. NAME OF PERMIT OR APPROVAL:

- Iron Ore Mining Lease or Taconite Iron Ore Mining Lease - Negotiated (S)

B. STATUTORY AUTHORITY:

- Minnesota Statutes, Sections 93.192, 93.20, and 93.335

C. TITLE OF REGULATION:

- None

D. SUMMARY OF PERMIT/APPROVAL PROCESS:

1. Applicability

- Under specified conditions, a party is eligible to apply for and negotiate a lease to mine iron ore from State-owned and State-administered 1 and

\section{General Requirements}

- Applicant eligible to negotiate lease under either of the following circumstances

- Applicant owns or is leasing for mining purposes iron ore adjacent to State ore; and the commissioner determines it is impracticable to mine such State ore except in conjunction with mining of the adjacent ore 
- State owns fractional undivided interest in property and remaining undivided interests are owned or held under lease for mining purposes by the applicant

3. Submission Requirements

- Application for lease with proposed terms

- Title information

- Mining operation data

- Ore estimates

- $\quad$ ther information as requested by commissioner

4. Procedures for Obtaining Permit or Approval

- MDNR reviews application and accompanying information

- Determination made if applicant eligible to negotiate lease

- Negotiations held

- Lease drafted if agreement reached

- State Executive Council must approve issuance of lease

5. Operations Requirements

- Applicant must comply with all applicable laws and any requirements set forth in the lease

6. Fees

- Annual Rentals:

Subject to negotiations, but not less than:

- Iron ore - $\$ 1,250$ first year, $\$ 5,000 / y r$ thereafter

- Taconite - $\$ 400 / y r$ first 5 years, $\$ 1,600 / y r$ thereafter

- Lease Royality - minimum rates per ton of ore, as specified in laws, plus additional negotiated rates; total royalty subject to escalation

7. Appeal Process

- No special appeal process enacted; appeal would be to district court 
CHAPTER 3.12 (concluded)

E. ADMINISTERING AGENCY:

Division of Minerals

Minnesota Department of Natural Resources

Box 45, Centennial Office Building

Saint Paul, Minnesota 55155

(612) 296-4807 
STOCKPILED IRON ORE PROSPECTING PERMIT AND MINING LEASE, STOCKPILED TACONITE IRON ORE PROSPECTING PERMIT AND MINING LEASE

\section{INTRODUCT ION}

The Division of Minerals, within the Minnesota Department of Natural Resources, has responsibility for issuing stockpiled iron ore or taconite iron ore prospecting permits and mining leases, under the authority of Minnesota Statuts, Chapter 93. The Commissioner of Natural Resources, with the approval of the State Executive Council, is authorized to issue prospecting permits and mining leases covering stockpiled iron ore.

A. NAME OF PERMIT OR APPROVAL:

- Stockpiled Iron Ore Prospecting Permit/Mining Lease or Stockpiled Taconite Iron Ore Prospecting Permit/Mining Lease

B. STATUTORY AUTHORITY:

- Minnesota Statutes, Sections 93.14 through 93.24, and 93.285

C. TITLE OF REGULATION:

- None

D. SUMMARY OF PERMIT/APPROVAL PROCESS:

1. App1icability

- Prospecting for and mining stockpiled iron ore belonging to the State or in which the State has an interest

2. General Requirements

- Any stockpiled iron ore may be designated as a stockpile mining unit for disposal separately from ore in the ground

- Stockpiled iron ore/taconite prospecting permits and mining leases are subject to al1 provisions of 1 aw relating to iron ore/taconite prospecting permits and mining leases (See Minnesota Statutes, Section 93.14 through 93.24); provided that the Commissioner of Natural Resources, with the approval of the State Executive Council, may include in any permit or lease such additional provisions, not inconsistent with the 
law, as he may deem advisable for the proper disposal of such ore in the furtherance of the public interest

- In case any stockpiled iron ore consisting of tailings from a treatment or beneficiation plant or other material shall be commingled with other such material owned or held under lease by another, the Commissioner of Natural Resources, with the approval of the State Executive Council, upon application of such owner or lessee, without public sale and without prior issuance of a prospecting permit, may enter into a mining lease with such owner or lessee for the removal and disposal of the State's portion of such commingled material

- Upon application of the holder of a stockpiled iron ore/taconite prospecting permit, the commissioner may, for good cause shown, extend the time for beginning the work of prospecting under the permit to not exceeding 6 months from the date of the permit

3. Submission Requirements

- Public sale - same requirements as in public sale of iron ore/taconite prospecting permits and mining leases

- Negotiated lease - same requirements as for negotiated iron ore/taconite mining leases

4. Procedures for Obtaining Permit or Approval

- Public sale - same procedure as in public sale of iron ore/taconite prospecting permits and mining leases

- Negotiated lease - same procedure as for negotiated iron ore/taconite mining lease

5. Operations Requirements

- Applicant must comply with all applicable laws and all requirements set forth in permit and lease

6. Fees

Permits and Leases issued through public sale - same fees as in iron ore/taconite prospecting permits and mining leases issued through public sale

- Negotiated 1eases - rental and royalty at such rates as may be agreed upon between the parties; provided that such rates 


\section{CHAPTER 3.13 (continued)}

shall not be less than minimums prescribed by law for iron ore/taconite mining leases

7. Appeal Process

- No special process enacted; appeal would be to district court

E. ADMINISTERING AGENCY:

Division of Minerals

Minnesota Department of Natural Resources

Box 45, Centennial office Building

Saint Paul, Minnesota 55155

(612) 296-4807 
PERMIT TO PROSPECT FOR AND LEASES TO MINE COPPER, NICKEL, AND ASSOC IATED MINERALS

\section{INTRODUCTION}

The Division of Minerals, within the Minnesota Department of Natural Resources (MDNR), has responsibility for issuing permits to prospect for and leases to mine copper, nickel, and associated minerals, under the authority of Minnesota Statutes, Chapter 93. The Commissioner of Natural Resources, with the approval of the State Executive Council, leases State-owned and State-administered 1 and for the purpose of prospecting for, mining, and removing copper, nickel, and associated minerals.

A. NAME OF PERMIT OR APPROVAL:

- Permit to Prospect for and Leases to Mine Copper, Nickel, and Associated Minerals (S)

B. STATUTORY AUTHORITY:

- Minnesota Statutes, Sections 93.08 through 93.12, and 93.25

C. TITLE OF REGULATION:

- Department of Natural Resources Rules and Regulations NR 94, Chapter 8 (P)

D. SUMMARY OF PERMIT/APPROVAL PROCESS:

1. Applicability

- Prospecting for mining and removing copper, nickel, and associated minerals from State-owned and State-administered lands

2. General Requirements

- Leases issued only upon pub1ic sale, except as otherwise expressly provided by law, unless the commissioner finds that it is impractical to hold a public sale on any mining unit because of its location or size or the extent of the State's interest in the minerals, and that the best interests of the State would be served thereby, the commissioner, with the approval of the executive council, may, without holding a 
CHAPTER 3.14 (continued)

public sale, issue a lease to any qualified applicant to prospect for, mine, and remove copper, nickel, and associated minerals

- First 2 years of any lease shall be deemed the prospecting permit

3. Submission Requirements

- Public Sale: For each mining unit, applicant submits

- Application and bid on form obtained from MDNR

- Application fee

- Application and bid form and check submitted in sealed bid envelope, obtained from MDNR

- Negotiated lease

- Application for lease with proposed lease terms

- Title information

- Any exploration data that is available

- $\quad$ ther information as requested by commissioner

4. Procedures for Obtaining Permit or Approval

- Public Sale:

- Applicant submits application to Commissioner of Natural Resources within time deadlines announced in public notice of sale

- Lease awarded by commissioner, with approval of State Executive Counci1, to highest bidder (bids must equal or exceed base rates specified in rules and regulations, and the right is reserved to reject any and all bids)

- Negotiated Lease:

- MNDR reviews submitted application and information

- Determination made if applicant eligible to negotiate lease 
CHAPTER 3.14 (continued)

- Negotiations held

- Lease drafted if agreement reached

- State executive council must approve issuance of lease

5. Operations Requirements

- Appplicant must comply with all applicable laws and all

6. Fees requirements set forth in the lease

- Application (Public Sale) - $\$ 50$

- Annual lease rentals - subject to negotiation, but not less than

- $\$ 1 /$ acre/year - unexpired portion first calendar year and next 5 years

- $\quad \$ 5 /$ acre/year - next 5 years

- $\quad \$ 25 /$ acre/year - remainder

- Lease royalties - Base rate, plus additional rate equivalent to the base rate on that portion of the value of the metals and mineral products recovered in the mill concentrate that exceeds $\$ 17$ per ton of dried crude ore, plus the bid rate

7. Appeal Process

- No special appeal process enacted; appeal would be to district court 
CHAPTER 3.14 (concluded)

E. ADMINISTERING AGENCY:

Division of Minerals

Minnesota Department of Natural Resources

Box 45, Centennial Office Building

Saint Paul, Minnesota 55155

(612) 296-4807 
LEASE FOR REMOVAL OF STOCKPILED IRON-BEARING MATERIAL

\section{INTRODUCTION}

The Division of Minerals, within the Minnesota Department of Natural Resources (MDNR), has responsibility for issuing leases for removal of stockpiled iron-bearing material, under the authority of Minnesota Statutes, Chapter 93. The Commissioner of Natural Resources is authorized to issue leases for the taking and removal of any paint rock, taconite, or other iron-bearing material belonging to the State, and containing not more than 40-percent dried iron, for use in construction.

A. NAME OF PERMIT OR APPROVAL:

- Lease for Removal of Stockpiled Iron-Bearing Material (S)

B. STATUTORY AUTHORITY:

- Minnesota Statutes, Section 93.41

C. TITLE OF REGULATION:

- None

D. SUMMARY OF PERMIT/APPROVAL PROCESS:

1. Applicability

- State-owned paint rock, taconite, or other iron-bearing material containing not more than 40-percent dried iron by analysis may be leased for use in construction

2. General Requirements

- In case the Commissioner of Natural Resources determines that any paint rock, taconite, or other iron-bearing material belonging to the State and containing no more than 40-percent dried iron by analysis is needed and suitable for use in the construction or maintenance of any road, tailings basin, settling basin, dike, dam, bankfill, or other works on public or private property, and that such use would be in the best interests of the public, he may authorize the disposal of this material 


\section{CHAPTER 3.15 (continued)}

3. Submission Requirements

Application must include the following

- Information about the applicant

- Amount of material which is wanted

- Location from which they would like to remove the material

- Desired length of term

4. Procedures for Obtaining Permit or Approval

- Applicant submits application to MDNR

- MDNR reviews application (additional information may be requested)

- Negotiations may be required

- MDNR issues or denies lease

5. Operations Requirements

- Applicant must comply with all applicable rules and regulations and any stipulations set forth in the permit

6. Fees

- $\quad$ Advance payment required - varies

- Payment per cubic yard determined by MDNR with negotiations of applicant, with minimums specified by Minnesota Statutes Section 93.41, subdivisions 2 and 3

7. Appeal Process

- No special process enacted; appeal would be to district court

E. ADM INISTERING AGENCY:

Division of Minerals

Minnesota Department of Natural Resources

Box 45, Centennial Office Building

Saint Paul, Minnesota 55155

(612) 296-4807 


\section{INTRODUCT ION}

The Division of Minerals, within the Minnesota Department of Natural Resources (MDNR), has responsibility for issuing horticultural or agricultural peat leases, under the authority of Minnesota Statutes, Chapter 92. The Commissioner of Natural Resources is authorized to lease any State-owned lands under his jurisdiction and control for the purpose of removing peat or for the purpose of using peat lands for agricultural purposes. Leases for the removal of peat are approved by the State Executive Council.

A. NAME OF PERMIT OR APPROVAL:

- Horticultural Peat Lease or Agricultural Peat Lease (S)

B. STATUTORY AUTHORITY:

- Minnesota Statutes, Section 92.50, Subdivision 1

C. TITLE OF REGULATION:

- None

D. SUMMARY OF PERMIT/APPROVAL PROCESS:

- May be by private or public vendue; process is currently being revised

E. ADMINISTER ING AGENCY:

Division of Minerals

Minnesota Department of Natural Resources

Box 45, Centennial Office Building

Saint Paul, Minnesota

(612) 296-4807 
CHAPTER 3.17

APPROVAL TO MINE UNDER PUBL IC WATERS

INTRODUCTION

The Division of Waters, within the Minnesota Department of Natural Resources (MDNR), has responsibility for issuing approvals to mine under public waters, under the authority of Minnesota Statues, Chapters 93 and 105. The purpose of this permit is to protect pub1ic waters.

A. NAME OF PERMIT OR APPROVAL:

- Approvar to Mine Under Public Waters (S)

B. STATUTORY AUTHORITY:

- Minnesota Statutes, Sections 93.34 and 105.42

C. TITLE OF REGULATION:

- Minnesota Code of Agency Rules, Title 6, Section 1.5022

D. SUMMARY OF PERMIT/APPROVAL PROCESS:

1. Applicability

- Any mining activities under public waters

2. General Requirements

- This permit must be obtained prior to engaging in any projects which may pertain to the "applicability" section above

3. Submission Requirements

- Detailed information about any of the following which are applicable to the project

- Filling into public waters

- Beach sand blankets

- Riprap shore protection

- Other filling

- Excavation of public waters

- Dredging

- Inland excavations connected to public waters

- Alterations of natural watercourses 
- Structures in public waters

- Permanent docks

- Wharves

- Offshore breakwaters, harbors, and marinas

- Retaining walls

- Other waterway obstructions

- Boat launching ramps

- Removal or abandonment

- Water-level controls and dam construction or reconstruction

- Bridge and culvert installation, water-mains and sewer crossings, intakes and outfalls

4. Procedures for Obtaining Permit or Approval

- Applicant submits application to MDNR

- Public hearing may be held of project is controversial

- Final review and decision by MDNR

5. Operations Requirements

- Applicant must comply with all applicable rules and regulations and any stipulations set forth in the permit

6. Fees

- Permit - $\$ 15$

- Processing (each water appropriation) - \$5

- Field inspection - Cost of field inspection or $\$ 25$ (whichever is greater)

\section{Appeal Process}

- Formal public hearing may be requested within 30 days of decision, then judicial review may be requested

E. ADMINISTERING AGENCY:

Division of Waters

Minnesota Department of Natural Resources

Space Center Building

444 Lafayette Road

Saint Paul, Minnesota 55155

(612) 296-4810 


\section{PERMIT FOR PROSPECTING FOR IRON ORE \\ IN THE BEDS OF STATE WATERS}

\section{INTRODUCTION}

The Division of Waters, within the Minnesota Department of Natural Resources (MDNR), has responsibility for issuing permits for prospecting for iron ore in the beds of State waters, under the authority of Minnesota Statutes, Chapters 93 and 105 . The purpose of this permit is to protect public waters.

A. NAME OF PERMIT OR APPROVAL:

- Permit for Prospecting for Iron Ore in the Beds of State Waters $(S)$

B. STATUTORY AUTHORITY:

- Minnesota Statutes, Sections 93.35 and 105.42

C. TITLE OF REGULATION:

- Minnesota Code of Agency Rules, Title 6, Section 1.5022

D. SUMMARY OF PERMIT/APPROVAL PROCESS:

1. Applicability

- Any prospecting for iron ore under the beds of State waters

2. General Requirements

- This permit must be obtained prior to engaging in any projects which may pertain to the "applicability" section above

3. Submission Requirements

- Detailed information about any of the following which are applicable to the project

- Filling into public waters

- Beach sand blankets

- Riprap shore protection

- Other filling 
- Excavation of public waters

- Dredging

- Inland excavations connected to public waters

- Alterations of natural watercourses

- $\quad$ Structures in public waters

- Permanent docks

- Wharves

- Offshore breakwaters, harbors, and marinas

- Retaining walls

- Other waterway obstructions

- Boat launching ramps

- Removal or abandonment

- Water-level controls and dam contruction or reconstruction

- Bridges and culvert installation, water-main and sewer crossings, intakes and outfalls

4. Procedures for Obtaining Permit or Approval

- Applicant submits application to MDNR

- Public hearing may be held if project is controversial

- Final review and decision by MDNR

5. Operations Requirements

- Applicant must comply with all applicable rules and regulations and any stipulations set forth in the permit

6. Fees

- $\quad$ Permit - $\$ 15$

- Processing (each water appropriation) - $\$ 5$

- Field inspection - Cost of field inspection or $\$ 25$ (whichever is greater)

7. Appea1 Process

- Formal appeal may be requested within 30 days of decision, then judicial review may be requested 
CHAPTER 3.18 (concluded)

E. ADMINISTER ING AGENCY:

Division of Waters

Minnesota Department of Natural Resources

Space Center Building

444 Lafayette Road

Saint Paul, Minnesota 55155

(612) $296-4810$ 


\section{PERMIT FOR PROSPECTING FOR MINERALS UNDER WATERS \\ OF LAKES AND STREAMS}

\section{INTRODUCTION}

The Division of Waters, within the Minnesota Department of Natural Resources (MDNR), has responsibility for issuing permits for prospecting for minerals under waters of lakes and streams, under the authority of Minnesota Statues, Chapters 93 and 105. The purpose of this permit is to protect public waters.

A. NAME OF PERMIT OR APPROVAL:

- Permit for Prospecting for Minerals Under Waters of Lakes and Streams (S)

B. STATUTORY AUTHORITY:

- Minnesota Statutes, Sections 93.08 and 105.42

C. TITLE OF REGULATION:

- Minnesota Code of Agency Rules, Title 6, Section 1.5022

D. SUMMARY OF PERMIT/APPROVAL PROCESS:

1. Applicability

- Any prospecting for minerals under waters of lakes and streams

2. General Requirements

- This permit must be obtained prior to engaging in any projects which may pertain to the "applicability" section above

3. Submission Requirements

- Detailed information about any of the following which are applicable to the project

- Filling into public waters

- Beach sand blankets

- Riprap shore protection

- Other filling 
- Excavation of public waters

- Dredging

- Inland excavations connected to public waters

- Alterations of natural watercourses

- Structures in public waters

- Permanent docks

- Wharves

- Offshore breakwaters, harbors and marinas

- Retaining walls

- Other waterway obstructions

- Boat launching ramps

- Removal or abandonment

- Water-level controls and dam construction or reconstruction

- Bridge and culvert installation, water-mains and sewer crossings, intakes and outfalls

4. Procedures for Obtaining Permit or Approval

- Applicant submits application to MDNR

- Public hearing may be held of project is controversial

- Final review and decision by MDNR

5. Operations Requirements

- Applicant must comply with all applicable rules and regulations and any stipulations set forth in the permit

6. Fees

- Permit - $\$ 15$

- Processing (each water appropriation) - $\$ 5$

- Field inspection - Cost of field inspection or \$25 (whichever is greater)

7. Appeal Process

- Formar public hearing may be requested within 30 days of decision, then judicial review may be requested 
CHAPTER 3.19 (concluded)

E. ADMINISTERING AGENCY:

Division of Waters

Minnesota Department of Natural Resources

Space Center Building

444 Lafayette Road

Saint Paul, Minnesota 55155

(612) 296-4810 


\section{LICENSE TO DEPOSIT TAILINGS FROM IRON ORE \\ IN ANY PUBLIC LAKE}

\section{INTRODUCTION}

The Division of Waters, within the Minnesota Department of Natural Resources (MDNR), has responsibility for issuing licenses to deposit tailings from iron ore in any public lakes, under the authority of Minnesota Statutes, Chapters 93 and 105. The purpose of this permit is to protect public waters.

A. NAME OF PERMIT OR APPROVAL:

- License to Deposit Tailings from Iron Ore in any Public Lake (S)

B. STATUTORY AUTHORITY:

- Minnesota Statutes, Sections 92.50 and 105.42

C. TITLE OF REGULATION:

- Minnesota Code of Agency Rules, Title 6, Section 1.5022

D. SUMMARY OF PERMIT/APPROVAL PROCESS:

1. Applicability

- Any prospecting for minerals under waters of lakes and streams

2. General Requirements

- This permit must be obtained prior to engaging in any projects which may pertain to the "applicability" section above

3. Submission Requirements

- Detailed information about any of the following which are applicable to the project

- Filling into public waters

- Beach sand blankets

- Riprap shore protection

- Other filling 
- Excavation of public waters

- Dredging

- Inland excavations connected to public waters

- Alterations of natural watercourses

- Structures in public waters

- Permanent docks

- Wharves

- Offshore breakwaters, harbors, and marinas

- Retaining walls

- Other waterway obstructions

- Boat launching ramps

- Removal or abandonment

- Water-level controls and dam construction or reconstruction

- Bridge and culvert installation, water-mains and sewer crossings, intakes and outfalls

4. Procedures for Obtaining Permit or Approval

- Applicant submits application to MDNR

- Public hearing may be held of project is controversial

- Final review and decision by MDNR

5. Operations Requirements

- Applicant must comply with all applicable rules and regulations and any stipulations set forth in the permit

6. Fees

- Permit - $\$ 15$

- Processing (each water appropriation) - $\$ 5$

- Field inspection - Cost of field inspection or \$25 (whichever is greater)

7. Appeal Process

- Formal public hearing may be requested within 30 days of decision, then judicial review may be requested 
CHAPTER 3.20 (concluded)

E. ADMINISTERING AGENCY:

Division of Waters

Minnesota Department of Natural Resources

Space Center Building

444 Lafayette Road

Saint Paul, Minnesota 55155

(612) $296-4810$ 
INTRODUCTION

The Division of Waters, within the Minnesota Department of Natural Resources (MDNR), has responsibility for issuing permits for drainage or diversion to facilitate mining, under the authority of Minnesota Statutes, Chapter 105. The purpose of this permit is to prevent improper drainage or diversion which could cause environmental degredation.

A. NAME OF PERMIT OR APPROVAL:

- Permit for Drainage or Diversion to Facilitate Mining (S)

B. STATUTORY AUTHORITY:

- Minnesota Statutes, Section 105.64

C. TITLE OF REGULATION:

- Minnesota Code of Agency Rules, Title 6, Sections 1.5000 and 1.5050 through 1.5058

D. SUMMARY OF PERMIT/APPROVAL PROCESS:

1. Applicability

- Any mining activities proposing to drain or diverge water

2. General Requirements

- This permit must be obtained prior to engaging in any projects which may pertain to the "applicability" section above

3. Submission Requirements

- A completed app1ication on forms supplied by the commissioner

- The required application fee (Minnesota Statutes 105.44, subdivision 10 ) 
- Aerial photographs, maps, sketches, detailed plat, topographic maps, or other descriptive data sufficient to show

- The location of the area of use

- The outline of the property owned or controlled by the applicant in proximity to the area of use

- The location of the proposed point of appropriation such as well(s) location, streambank pumps(s) or the location of other facilities for appropriation of water

- If ground water is involved, the location of test-hole borings which have been drilled on the property from which the appropriation will be made

- Signed statement that copies of the application and accompanying documents have been sent to the mayor of the city and the Secretary of the Board of Supervisors of the Soil and Water Conservation District or the Secretary of the Board of Managers of the Watershed District if the proposed project is within a county or within or affects a watershed district or soil and water conservation district

Statement of justification supporting the reasonableness and practicality of use with respect to adequacy of the water source, amounts of use and purposes, including available facts on

- Hydrology and hydraulics of the water sources involved, including for surface waters, the applicant's analysis of the effect of proposed withdrawals on level and flows and anticipated impacts, if any, on instream flow or lake-level conditions to the extent that such facts are not al ready available to the commissioner

- Proposed pumping schedule including rates, times and duration

- Amounts of water to be appropriated on a maximum daily, monthly, and annual basis

- Means, methods, and techniques of appropriation

- Alternative sources of water or methods which were considered, to attain the appropriation objective and why the particular alternative proposed in the application was selected

- Information on any water storage facilities and capabilities and any proposed reuse and conservation practices 
- Application for use of surface water shall include the following additional data:

- A contingency plan which describes the alternatives the applicant will utilize if any time appropriation is restricted to meet instream flow needs or to protect the level of a basin. The contingency plan shall be feasible, reasonable and practical, otherwise the applicant must submit, as part of the application, a written statement agreeing in such case to withstand the results of no appropriation

- For appropriation from natural basins or natural watercourses, facts showing that reasonable al ternatives for appropriating water have been considered including use of water approriated during high flows and levels and stored for later use and the use of ground water

- For basins less than 500 acres in surface area the applicant must notify a11 riparian landowners and provide the commissioner with a list of all landowners notified

- Attempt to obtain a signed statement from as many riparian landowners as the applicant is able to obtain stating their support to the proposed appropriation

- Provide an accounting of number of signatures of riparian owners the applicant is unable to obtain

Application for use of ground water, except for agricultural irrigation sha11 include the following data:

- Test hole logs (if any) and water well record(s)

- Hydrologic test data

- Hydrologic studies

- If the above data are insufficient to allow the commissioner to properly assess the capability of the aquifer system in the area of withdrawal or are inadequate to allow assessment of the effects of the proposed appropriation on the water resource and on nearby wells

4. Procedures for Obtaining Permit or Approval

- Applicant submits application to MDNR

- Public hearing may be held if project is controversial

- Final review and decision by MDNR

5. Operations Requirements

Applicant must comply with all applicable rules and regulations and any stipulations set forth in the permit 
CHAPTER 3.21 (concluded)

6. Fees

7. Appeal Process

- Formal public hearing may be requested within 30 days of decision, then judicial review may be requested

E. ADMINISTERING AGENCY:

Division of Waters

Minnesota Department of Natural Resources

Space Center Building

444 Lafayette Road

Saint Paul, Minnesota 55155

(612) $296-4810$ 
SECTION 4.0

LAND USE REGULATIONS

580 
CHAPTER 4.1

ROUTING HIGH-VOLTAGE TRANSMISSION LINES AND SITING LARGE ELECTRIC POWER GENERATING PLANTS PERMITS

\section{INTRODUCTION}

The Environmental Quality Board $(E Q B)$, within the Minnesota Department of Energy, Planning, and Development, determines routes for transmission lines capable of operating at 200 kilovolts (kV) or larger and issues construction permits, under the authority of the Power Plant siting Act. The purpose of this permit is to insure proper construction of powerp1ants and correct routes for transmission 1 ines.

A. NAME OF PERMIT OR APPROVAL:

- Construction Permit (S)

B. STATUTORY AUTHORITY:

- The Power Plant Siting Act

- Minnesota Statutes 1980, Section $116 \mathrm{C} .51$ et seq.

C. TITLE OF REGULATION:

- Minnesota Code of Agency Rules, Title 6, Sections 3.071 through 3.082

D. SUMMARY OF PERMIT/APPROVAL PROCESS:

1. Applicability

- Any utility desiring to construct a high-transmission line of 200 kilovolts (kV) or more

2. General Requirements

- There is no special application form, al though the application must be consistent in form with a draft environmental impact statement as outlined in EQB's Environmental Review Program Rules

- Any utility wishing to construct such a transmission line must first obtain a construction permit from the EQB 
CHAPTER 4.1 (continued)

- The permit is suspended if construction has not begun within 4 years of approval

3. Submission Requirements

- Size and type of the proposed transmission line

- At least 2 proposed routes for the proposed transmission line

- An environmental analysis of each proposed route, including a description of the environmental setting and the potential environmental impacts of each route

- Engineering and operational design concepts for the proposed transmission line

- Description of the construction, right-of-way preparation, and maintenance procedures anticipated for the proposed transmission line

- $\quad$ Procedures and practices proposed for the ultimate abandonment and restoration of the right-of-way

- Listing of Federal or State permits that may be required for the proposed transmission line

- Cost analysis of each route

- Certificate of need, if available, or an acknowledgment of the acceptance of a substantially complete certificate of need application by the Minnesota Energy Agency, if a certificate of need is required by Minnesota Statutes, Section $116 \mathrm{H}$

- Statement of proposed ownership of the facility as of the day of filing and an affidavit authorizing the applicant to act on behalf of those planning to participate in the project

- Information necessary to evaluate impact of proposed routes on human settlement, economic operations, natural environment and public lands, reliability, cost and accessibility, and special designated lands, So EQB can apply methods to minimize adverse impacts

4. Procedures for Obtaining Permit or Approval

- Utility submits application to $E Q B$ 
- EQB reviews application for completeness before formally accepting it; formal notice of acceptance is given

- $\quad E Q B$ undertakes a yearlong selection process that involves:

- technical and environmental analyses of all alternative routes (EQB can consider alternative routes in addition to those proposed by utility)

- consultation with participation by all affected Federal, State, and local agencies

- public hearings and meetings and a citizens' route evaluation committee

- findings of fact and recommendation of a route by an independent hearing examiner, who conducts the public hearings

- $E Q B$ designates the route and sets conditions to minimize adverse effects

- At least 60 days prior to construction initiation, utility submits preliminary construction plans to $E Q B$ for review for compliance (EQB also monitors construction activities for compliance)

- Total processing time, 12-18 months

- Procedures for emergency certification, exempting lines that have no significant human or environmental effects, and reviewing minor alterations to permit is also available

5. Operations Requirements

- Utility must comply with conditions in construction permit

- Utility gives $E Q B$ preliminary construction plans at

least 60 days prior to construction initiation

- $E Q B$ monitors the plans and construction activities to ensure compliance

6. Fees

- Utility pays amount needed to process application in 4 installments

- $\$ 35,000$ plus $\$ 1,000$ per mile of longest proposed route 
CHAPTER 4.1 (concluded)

- Surplus is returned to utility

7. Appea1 Process

- Appear is to the appropriate district court

E. ADMINISTERING AGENCY:

Acting Manager

Power Plant Siting Program

Minnesota Environmental Quality Board

Department of Energy, Planning, and Development

Capitol Square Building

550 Cedar Street

Saint Pau1, Minnesota 55101

(612) $296-2723$ 
CHAPTER 4.2

CERT IF ICATE OF SITE COMPATIBIL ITY

\section{INTRODUCTION}

The Environmental Quality Board (EQB), within the Minnesota Department of Energy, Planning, and Development, determines sites and issues certificates of site compatibility for powerplants 50 megawatts or greater, under the authority of the Power Plant Siting Act. The purpose of this permit is to site powerplants to minimize human and environmental impact and to ensure electric power system reliability.

A. NAME OF PERMIT OR APPROVAL:

- Certificate of Site Compatibility (S)

B. STATUTORY AUTHORITY:

- The Power Plant Siting Act

- Minnesota Statutes 1980, Section $116 \mathrm{C} .51$ et seq.

C. TITLE OF REGULATION:

- Minnesota Code of Agency Rules, Title 6, Sections 3.071 through $3.082(P)$

D. SUMMARY OF PERMIT/APPROVAL PROCESS:

1. Applicability

- Any utility desiring to construct a powerplant 50 megawatts or greater

2. General Requirements

- There is no special application form, although the application must be consistent in form with an environmental report as outlined in EQB's Environmental Review Program Rules

- Construction must begin within 4 years after one certificate is granted 
CHAPTER 4.2 (continued)

3. Submission Requirements

- Size and type of the proposed plant

- At least 2 proposed sites for the proposed plant

- Engineering and operational design concepts for the plant at each of the proposed sites

- Engineering analysis of each of the proposed sites

- Procedures and practices proposed for the ultimate abandonment and restoration of the site

- Environmental analysis of each proposed site, including a description of the environmental setting and the potential environmental impacts of each site

- Cost analysis of the plant at each proposed site

- Listing of Federal or State permits that may be required for each proposed site

- Certificate of need, if available, or an acknowledgment of the acceptance of a substantially complete certificate of need application by the Minnesota Energy Agency, if a certificate of need is required

- Statement of proposed ownership of the facility as of the day of filing and an affidavit authorizing the applicant to act on behalf of those planning to participate in the project

- Information necessary to evaluate impact of proposed sites on EQB-designated exclusion areas, avoidance areas, and one site-selection criteria

4. Procedures for Obtaining Permit or Approval

- Utility submits application to $E Q B$

- $\quad E Q B$ reviews application for completeness before formally accepting it; formal notice of acceptance is given

- $E Q B$ undertakes a yearlong selection process that involves:

- technical and environmental analyses of all alternative sites (EQB can consider al ternative sites in addition to those proposed by utility) 
- consultation with and participation by all affected Federal, State, and local agencies

- public hearings and meetings and a citizens' advisory committee

- $E Q B$ selects site and sets conditions to minimize adverse impacts

- $\quad E Q B$ requires applicant to supply $p 1$ ans and data to ensure compliance with conditions

- Total estimated processing time, 12-18 months

- Procedure for emergency certification is also available

5. Operations Requirements

- Following approval, utility must comply with conditions in certificate (EQB may require utility to supply plans and data to ensure compliance)

6. $\quad$ Fees

- Utility pays amount needed to process application in 4 installments - no more than $\$ 1,000$ for each $\$ 1$ million of production plant investment in the property installation, as defined in the Federal Power Comission Uniform System of Accounts

7. Appeal Process

- Appeal is to the appropriate district court

E. ADMINISTERING AGENCY:

Acting Manager

Power Plant Siting Program

Environmental Quality Board

Minnesota Department of Energy, Planning, and Development

Capitol Square Building

550 Cedar Street

Saint Paul, Minnesota 55101

(612) $296-2723$ 


\section{ABANDONED PROPERTY SEARCH AND/OR DISPOSITION PERMIT}

\section{INTRODUCTION}

The Real Estate Management Division, within the Department of Administration has responsibility for issuing permits for abandoned property search and/or disposition, under the authority of Minnesota Statutes, Chapter 16. This permit must be obtained prior to searching for or disposing of abandoned or lost property on lands owned by the State of Minnesota. Any person wishing to search upon lands owned by the State of Minnesota for lost or abandoned property and/or dispose of abandoned or lost property must obtain a permit from the Department of Administration, Real Estate Management Division.

A. NAME OF PERMIT OR APPROVAL:

- Abandoned Property Search and/or Disposition Permit (S)

B. STATUTORY AUTHORITY:

- Minnesota Statutes, Sections 16.021 through 16.023

C. TITLE OF REGULATION:

- Minnesota Code of Agency Rules, Title 2, Sections 1.5202 through 1.5205

D. SUMMARY OF PERMIT/APPROVAL PROCESS:

1. Applicability

- Any person wishing to search for and/or dispose of lost of abandoned property in Minnesota

2. General Requirements

- No special application form is required

3. Submission Requirements

- Applications must be made in writing to the Real Estate Management Division

- Name, mailing address, and telephone number 
- Describe proposed search

- Specify the area to be searched

4. Procedures for Obtaining Permit or Approval

- Applicant submits application to the Commissioner of Administration or his designee

- The commissioner then determines department jurisdiction over the 1 ands concerned,

- determines the necessity for liability insurance

- prepares a written agreement between the State and the applicant

- The written agreement is then submitted to the State Department of Finance and the Attorney General's Office for review and signature

- Upon execution of the written agreement the permit shall be in effect under the time and condition thereof

5. Operations Requirements

- Permittee shall indemnify and hold the State harmless for any claim and for any clauses of action

- If liability insurance is deemed necessary, minimum coverage per person per occurrence shall be no less than $\$ 100,000$ and minimum coverage per occurrence shall be no less than $\$ 500,000$

- Permittee shall obey all Federal, State and local laws, rules, and ordinances

- Permittee shall cause no damage to any property by virtue of its activities

- Permittee shall not adversely affect the environment and shall restore areas of activity to original condition

- Permittee shall removal all equipment relating to and debris resulting from its activities

- Permittee shall limit the activities to area specified in the permit 
- Permittee shall not assign or transfer any rights or obligations under the permit without prior consent of the Department of Administration

- Receipt of the permit shall not constitute an exclusive grant. The State may issue similar or identical permits for the same or overlapping areas of land

- The permit may be cancelled by either parties upon 30 days' written notice to the other party

- Unless specifically excepted for cause in the permit, all permits shall be granted with the understanding that the loss of abandoned property which is recovered from the State 1 ands shall be turned over to the Department of Administration for disposition as provided by statute. The permittee's share of the proceeds shall be agreed upon between the permittee and the State prior to issuance of the permit. The State's share shall be deposited in the general revenue fund

6. Fees

- Permittee and State agree to share proceeds from disposition of any property in the permit agreement

7. Appeal Process

- Court of Law

E. ADMINISTERING AGENCY:

Division of Real Estate Management

Department of Administration

G-22 Administration Building

Saint Paul, Minnesota 55155

(612) $296-6674$ 
ENVIRONMENTAL IMPACT STATEMENTS

\section{INTRODUCTION}

The Environmental Quality Board (EQB), within the Minnesota Department of Energy, Planning, and Development, has responsibility for reviewing an environmental impact statement (EIS), under the authority of the Environmental Impact Statement Rules. The purpose of an EIS is to provide information for agencies and private persons to evaluate proposed actions which have the potential for significant environmental effects, to consider alternatives, and to institute methods for reducing adverse environmental effects.

A. NAME OF PERMIT OR APPROVAL:

- Environmental Impact Statements (S)

B. STATUTORY AUTHORITY:

- Minnesota Statutes, Section 116D.04, Subdivision 2 (1974)

C. TITLE OF REGULATION:

- Minnesota Environmentar Policy Act of 1973

- Environmental Impact Statement Rules

- Minnesota Code of Agency Rules, Title 6, Section 3.026

D. SUMMARY OF PERMIT/APPROVAL PROCESS:

1. Applicability

- All actions that are major actions and/or have the potential for significant environmental effects

2. General Requirements

- Environmental Assessment Worksheets must be filed on all projects which fall within one of the categories of the rules 
3. Submission Requirements

- Draft EIS

- Comments or summaries received through consultation and public comment including public meetings or hearings held on the EIS

- Response of the responsible agency or responsible person to the significant environmental issues raised in the consultation, comment, and review process

4. Procedures for Obtaining Permit or Approval

- EIS's must be submitted to the proper State agencies

5. Operations Requirements

- Applicant must comply with all applicable rules, regulations, and stipulations set forth in the Environmental Review Program

6. Fees

- None

7. Appeal Process

- Judicial appeal process (process pending as of 24 September 1981)

E. ADMINISTERING AGENCY:

Environmental Review Program

Environmental Quality Board

Minnesota Department of Energy, Planning, and Development

101 Capitol Square Road

550 Cedar Street

Saint Paul, Minnesota 55101

(612) $296-2723$ 


\section{APPROVAL OF PIPELINE PLANS}

\section{INTRODUCTION}

The Minnesota Department of Natural Resources (MDNR) has responsibility for approving pipeline plans, under the authority of Minnesota Statutes, Chapter 117. The purpose of this permit is to ensure proper pipeline plans to prevent unsafe conditions.

A. NAME OF PERMIT OR APPROVAL:

- Approval of Pipelines (S)

B. STATUTORY AUTHORITY:

- Minnesota Statutes, Section 117.49

C. TITLE OF REGULATION:

- None

D. SUMMARY OF PERMIT/APPROVAL PROCESS:

1. Applicability

- Any proposed pipeline for transporting crude petroleum, oil, and their related products and derivatives, including

liquefied hydrocarbons, where the right of eminent domain is to be exercised for acquisition of the right-of-way (Does not apply to natural gas pipelines)

2. General Requirements

- Prior to the use of the right of eminent domain to acquire right-of-way for a pipeline, the plans for the project must be approved by the commissioner of MDNR

3. Submission Requirements

- Plans must be submitted in sufficient detail for the commissioner to make a determination of the impact the proposed project will have on the environment 
4. Procedures for Obtaining Permit or Approval

- Applicant submits letter of application and plans to MDNR, office of Planning, for review

- An environmental assessment or an environmental impact statement may be prepared

- MDNR commissioner makes recommendations as to any changes which must be made before approval can be granted

- When proposal is acceptable, approval is granted, and right-of-way acquisition may begin

5. Operations Requirements

- MDNR approval does not govern the operational phase of pipeline projects

6. Fees

- None

7. Appeal Process

- Appeal of the commissioner's decision must be made in district court

E. ADMINISTERING AGENCY:

Assistant Commissioner for Planning

Minnesota Department of Natural Resources

Box 51, Centennial Building

658 Cedar Street

Saint Paul, Minnesota 55155

(612) $296-4796$ 


\section{INTRODUCTION}

The Bureau of Lands, within the Minnesota Department of Natural Resources (MDNR), has responsibility for issuing permits for utility crossings of public lands and waters, under the authority of Minnesota Statutes, Chapter 84. The purpose of this permit is to protect the environment where these utilities cross.

A. NAME OF PERMIT OR APPROVAL:

- Permit for Utility Crossings of Public Lands and Waters (S)

B. STATUTORY AUTHORITY:

- Minnesota Statutes, Section 84.415

C. TITLE OF REGULATION:

- Minnesota Regulations, Chapters 5100 through 5102

D. SUMMARY OF PERMIT/APPROVAL PROCESS:

1. Applicability

- Any type of utility including lines, cables, or conduits for telephone, telegraph, or electric power, either above or below ground; and pipelines for gases, liquids, or solids in suspension

2. General Requirements

- A permit must be obtained from MDNR prior to any utility crossing of public lands and/or waters

- The proposal must meet the design, construction, safety, and right-of-way maintenance standards and criteria set forth in the regulations

3. Submission Requirements

- Legal description of lands affected 
- Maps

- Structure design

- Statement indicating applicant's plans comply with the environmental standards set forth in the regulations

- Other information as the commissioner may require

4. Procedures for Obtaining Permit or Approval

- Applicant submits application to Bureau of Lands which coordinates review with field staff and various MDNR divisions

- Timber damage, if any, is appraised by Division of Forestry

- License is issued by the MDNR within 25 to 45 days

5. Operations Requirements

- Compliance with all terms and conditions of the license is required, which may include operational requirements, such as maintenance of the right-of-way, notification when utility is to enter right-or-way or of intention to apply herbicides, etc.

6. Fees

- Based on type of utility, length of crossing, whether overhead or underground, and width of right-of-way

7. Appeal Process

- None

E. ADMINISTERING AGENCY:

Administrator

Bureau of Lands

Minnesota Department of Natural Resources

Box 31, Centennial Building

658 Cedar Street

Saint Pau1, Minnesota 55155

(612) 296-0659 
CHAPTER 4.7

LEASE ALLOWING USE OF STATE LANDS FOR TACONITE MINING

INTRODUCTION

The Bureau of Lands, within the Minnesota Department of Natural Resources (MDNR), has responsibility for issuing leases allowing use of State Lands for taconite mining, under the authority of Minnesota Statutes, Chapter 117. The purpose of this permit is to prevent environmental degredation to State lands caused by mining activities.

A. NAME OF PERMIT OR APPROVAL:

- Lease Allowing Use of State Lands for Taconite Mining (S)

B. STATUTORY AUTHORITY:

- Minnesota Statutes, Section 117.47

C. TITLE OF REGIULATION:

- None

D. SUMMARY OF PERMIT/APPROVAL PROCESS:

1. Applicability

- Deposition of Taconite Tailings

2. General Requirements

- Lease is permissive only if all other Federal, State and local regulations are complied with before, during, and after the term of the lease

3. Submission Requirements

- Legal description of land involved

- Plans and profiles of proposed operators

- Maps showing location and dimensions of all structures and support equipment 
4. Procedures for Obtaining Permit or Approval

- Applicant submits application to MDNR (No lease issued under this statute in the last 10 years)

- Information is reviewed by MDNR for completeness and technical soundness

- Depending on size of proposed operation, public notice may be required of other agencies before operation can begin

- Total estimated processing time - 2-4 months

5. Operations Requirements

- No standard or published operations requirements, requirements vary with each lease

6. Fees

- Fees are usually based on tonnage deposited on State land

7. Appeal Process

- None

E. ADMINISTERING AGENCY :

Administrator

Bureau of Lands

Minnesota Department of Natural Resources

Centennial Office Building, Box 31

658 Cedar Street

Saint Paur, Minnesota 55155 


\section{LEASE ALLOWING USE OF STATE LANDS FOR ACTIVITIES RELATED TO} COPPER AND NICKEL MINING

\section{INTRODUCTION}

The Bureau of Lands, within the Minnesota Department of Natural Resources (MDNR), has responsibility for issuing leases allowing use of State lands for activities related to copper and nickel mining, under the authority of Minnesota Statutes, Chapter 93. The purpose of this permit is to prevent environmental degredation to State lands caused by mining activities.

A. NAME OF PERMIT OR APPROVAL:

- Lease Allowing Use of State Lands for Activities Related to Copper and Nickel Mining (S)

B. STATUTORY AUTHORITY:

- Minnesota Statutes, Section 93.43

C. TITLE OF REGULATION:

- None

D. SUMMARY OF PERMIT/APPROVAL PROCESS:

1. Applicability

- All surface use of MDNR administered land in connection with activities related to copper and nickel mining

\section{General Requirements}

- Lease is permissive only if other Federal, State and local regulations are complied with before, during, and after term of lease

3. Submission Requirements

- No lease has ever been issued under this statute, therefore no requirements exist 
4. Procedures for Obtaining Permit or Approval

- No lease has ever been issued under this statute, therefore no procedures exist

5. Operations Requirements

- No lease has ever been issued under this statute, therefore no operations requirements exist

6. Fees

- Fees are a percent of land value plus any necessary monitoring fee as per requirements

7. Appeal Process

- None

E. ADMINISTERING AGENCY :

Administrator

Bureau of Lands

Minnesota Department of Natural Resources

Centennial Office Building, Box 31

658 Cedar Street

Saint Paul, Minnesota 55155

(612) 296-4097 
CHAPTER 4.9

CERT IF ICATE OF NEED FOR CONSTRUCTION OF LARGE ENERGY FACILITIES

INTRODUCTION

The Minnesota Energy Agency (MEA) has responsibility for issuing certificates of need for construction of large energy facilities, under the authority of Minnesota Statutes, Chapter 116. The purpose of this permit is to ensure proper construction of these facilities for the safety of all persons.

A. NAME OF PERMIT OR APPROVAL:

- Certificate of Need for Construction of Large Energy Facilities (S)

B. STATUTORY AUTHORITY:

- Minnesota Statutes, Section $116 \mathrm{H} .13$

C. TITLE OF REGULATION:

- Minnesota Code of Agency Rules, Title 6, Sections 2.0601 through

2.0641, Sections 2.0701 through 2.0791, Sections 2.0801 through

2.0881 , Sections 2.0901 through 2.0981, Sections 2.1001 through

2.1091, and Sections 2.1101 through 2.1186

D. SUMMARY OF PERMIT/APPROVAL PROCESS:

1. Applicability

- Generating plants, transmission lines, petroleum and natural gas pipelines, energy storage facilities, coal slurry pipelines, coal transshipment facilities, fuel conversion facilities, nuclear processing facilities, and nuclear waste storage or disposal

2. General Requirements

- A comprehensive application must be submitted in a form prescribed by the MEA Director 
CHAPTER 4.9 (continued)

3. Submission Requirements

- Requirements differ depending on facility type; in general, application must contain:

- Description of facility

- Evaluation of al ternatives to facility

- Historical and forecast data on applicant's system capacity and energy requirements

- Environmental data related to the project

- Discussion of conservation techniques applicant will be utilizing to reduce energy demand

4. Procedures for Obtaining Permit or Approval

- Applicant submits application to MEA Director

- MEA reviews application for completeness and requests assignment of State

- State hearing examiner holds hearing(s) and makes recommendations on approva1/disapproval to MEA Director

- MEA Director approves/disapproves application and issues/ denies certificate of need

- Statutory time limit for processing an application, 6 months

5. Operations Requirements

- Following approval, facility operations must comply with certificate conditions imposed by the director

6. $\quad$ Fees

- Fees, established in agency rules, are based on the output or capacity of the facility and the difficulty in assessing the need

- The fee is not to exceed $\$ 50,000$ (except $\$ 100,000$ limit for electric generating plants and transmission lines)

- A rehearing may require an additional fee 
CHAPTER 4.9 (concluded)

7. Appea1 Process

- Applicant may appeal to director for rehearing if application is denied

- Applicant may reapply for certificate if there are new facts which might alter director's judgment on need issue

- 30-day appeal period for any party

- 10-day appeal period for filing with Minnesota Environmental Quality Board

- Possibly court appears (Minnesota Environmental Rights Act, 116B)

E. ADMINISTERING AGENCY:

Manager

Minnesota Energy Agency

980 American Center Building

150 East Kellogg Boulevard

Saint Paul, Minnesota 55101

(612) 296-5120 


\section{INTRODUCTION}

The Permits Unit, within the Minnesota Department of Transportation (MDOT), has responsibility for issuing right-of-way and limited land use permits, under the authority of Minnesota Statutes, Chapter 160 . The purpose of this permit is to regulate the use of the highways.

A. NAME OF PERMIT OR APPROVAL:

- Right-of-way and Limited Land Use Permits (S)

B. STATUTORY AUTHORITY:

- Minnesota Statutes, Sections 160.27 and 161.434

C. TITLE OF REGULATION:

- Federal Highway Administration Manual, Volume 7, Chapter 4, Section 1

- Minnesota Statutes, Sections 160.27 and 161.434

D. SUMMARY OF PERMIT/APPROVAL PROCESS:

1. Applicability

- Use of right-of-way for particular uses, such as telephone booths, benches and shelters, custom inspection stations, and public notices

2. General Requirements

- No special application form

- There must be a written agreement between MDOT and an outside party to authorize use of existing highway right-of-way, such as for telephone booths, shelters, customs stations, public notices, bicycle and snowmobile paths, gardens, and parking lots 
3. Submission Requirements

- Request, including plans and details (it should be shown that mutual benefits can be derived by the outside agency and/or the general public and MDOT)

4. Procedures for Obtaining Permit or Approval

- Applicant submits request to MDOT district office

- A meeting is usually held to discuss details

- If benefits can be derived, a draft is written up

- MDOT legal section inspects draft

- Final draft is drawn up and executed

- Total estimated processing time, approximately 1 month

5. Operations Requirements

- None; however, agreement may contain specifications to follow

6. Fees

- None; except when there is a financial advantage for the permittee

7. Appeal Process

- None; agreement based on statutes and reasonableness

E. ADMINISTERING AGENCY:

District Engineer

Permits Section

Minnesota Department of Transportation

Address of District office in which located 


\section{INTRODUCTION}

The Permits Unit, within the Minnesota Department of Transportation (MDOT), has responsibility for issuing drainage permits, under the authority of Minnesota Statutes, Chapter 160. The purpose of this permit is to regulate drainage to highway drains.

A. NAME OF PERMIT OR APPROVAL:

- Drainage Permit $(S)$

B. STATUTORY AUTHORITY:

- Minnesota Statutes, Section 160.20

C. TITLE OF REGULATION:

- Minnesota Statutes, Section 160.20

D. SUMMARY DF PERMIT/APPROVAL PROCESS:

1. Applicability

- Connecting drains to highway drains

2. General Requirements

- Form TP-30795-02 must be used

3. Submission Requirements

- Type of drainage

- Area

- Casing size and type of pipe

4. Procedures for Obtaining Permit or Approval

- Applicant submits application to MDOT 
CHAPTER 4.11 (continued)

- Application is routed through various MDOT sections for comments before final approval

- Total estimated processing time, 2-5 weeks

5. Operations Requirements

- Applicant must comply with all applicable rules and regulations and any stipulations set forth in the permit

6. Fees

- None; however, a deposit may be required

7. Appeal Process

- None; permit based on statutes and reasonableness

E. ADMINISTERING AGENCY:

Permits Unit

Minnesota Department of Transportation

Address of District office in which located 
CHAPTER 4.12

ACCESS DRIVEWAY PERMIT

INTRODUCT ION

The Permits Unit, within the Minnesota Department of Transportation (MDOT), has responsibility for issuing access driveway permits, under the authority of Minnesota Statutes, Chapter 160. The purpose of this permit is to regulate construction projects on State highways.

A. NAME OF PERMIT OR APPROVAL:

- Access Driveway Permit (S)

B. STATUTORY AUTHORITY:

- Minnesota Statutes, Section 160.18

C. TITLE OF REGULATION:

- Minnesota Code of Agency Rules, Title 14, Section 1.5036

- Minnesota Regulation Highway 36

D. SUMMARY OF PERMIT/APPROVAL PROCESS:

1. Applicability

- Constructing an access or driveway off a State trunk highway

2. General Requirements

- Form 1721 must be used

3. Submission Requirements

- Application

- A sketch of the property

- Present and proposed driveways

- Relation to trunk highway 


\section{CHAPTER 4.12 (continued)}

4. Procedures for Obtaining Permit or Approval

- Applicant submits application to MDOT

- Application is routed through various MDOT sections and the municipality, if applicable, for comments before making a final approval

- Total estimated processing time, 2-5 weeks

5. Operations Requirements

- Applicant must comply with all applicable rules and regulations and any stipulations set forth in the permit

6. Fees

- None; however, a deposit may be required

7. Appeal Process

- None; permit based on statutes and reasonableness

E. ADMINISTERING AGENCY:

Permits Unit

Minnesota Department of Transportation

Address of District Office in which located 
SECTION 5.0

ENVIRONMENTAL QUALITY MANAGEMENT 
CHAPTER 5.1

PERMIT TO CHANGE THE COURSE, CURRENT, OR CROSS SECTION OF PUBL IC WATERS

INTRODUCTION

The Division of Waters, within the Minnesota Department of Natural Resources (MDNR), has responsibility for issuing permits to work in the beds of public waters, under the authority of Minnesota Statutes, Chapter 105. The purpose of this permit is to ensure that changes in the course, current, or cross section of public waters meet with State regulations.

A. NAME OF PERMIT OR APPROVAL:

- Permit to Change the Course, Current, or Cross Section of Public Waters (S)

B. STATUTORY AUTHORITY:

- Minnesota Statutes, Chapter 105

C. TITLE OF REGULATION:

- Minnesota Code of Agency Rules, Title 6, Sections 1.5000, 1.5020 through 1.5026 , and 1.5030 through 1.5034

D. SUMMARY OF PERMIT/APPROVAL PROCESS:

1. Applicability

- Any and all work which will cause or result in the alteration of the course, current, or cross section of public waters

2. General Requirements

- The activity must meet all rules and regulations and any stipulations set forth by the State

3. Submission Requirements

- Vary with type of work proposed 
- Commissioner may require any information deemed necessary

- All applications must include a completed application form, maps, sketches, drawings, plans and/or photos, as appropriate; statements regarding the anticipated changes in water and related land resources; detrimental effects on natural resources, and alternatives

4. Procedures for Obtaining Permit or Approval

- Applicant submits permit application to MDNR Regional hydrologist, with copies to city or county, soil and water conservation district, and watershed district as applicable

- Application is reviewed by Regional Hydrologist who makes field inspections and, if necessary, coordinates with other MDNR divisions and other agencies

- Permit decision is made by either Commissioner, Division Director or Regional Hydrologist, depending on type of proposal

- Decision must be made in 30 to 90 days

- Public hearing may be held under various authorities, either before or after the decision, if requested

5. Operations Requirements

- Permittee must comply with all terms and conditions set forth in the permit

6. Fees

- Application - $\$ 15$

- Inspection - $\$ 25$ and up to full cost of inspection

7. Appeal Process

- Applicant, city, watershed district, or soil and water conservation district may request a hearing within 30 days of the decision 
CHAPTER 5.1 (concluded)

E. ADMINISTERING AGENCY:

Director

Division of Waters

Minnesota Department of Natural Resources

Box 32, Centennial Building

658 Cedar Street

Saint Paul, Minnesota 55155

(612) 296-4810 
CHAPTER 5.2

PERMIT FOR APPROPRIATION OF WATERS OF THE STATE OF MINNESOTA

INTRODUCTION

The Division of Waters, within the Minnesota Department of Natural Resources (MDNR), has responsibility for issuing permits for appropriation of waters of the State of Minnesota, under the authority of Minnesota Statutes, Chapter 105.

A. NAME OF PERMIT OR APPROVAL:

- Permit for Appropriation of Waters of the State of Minnesota (S)

B. STATUTORY AUTHORITY:

- Minnesota Statutes, Chapter 105

C. TITLE OF REGULATION:

- Minnesota Code of Agency Rules, Title 6, Sections 1.5000, and 1.5050 through 1.5058

D. SUMMARY OF PERMIT/APPROVAL PROCESS:

1. Applicability

- Appropriation of waters of the State, except for:

- Domestic use serving 25 persons or less

- Test pumping of a ground-water source

- Any use at a rate of less than 10,000 gallons/day and totaling less than 1 million gallons/year

- Agricultural field tiles or ditches

- Reuse and discharge of permitted appropriations

2. General Requirements

- Any appropriation must be consistent with laws and rules of Federal, State and local government 
3. Submission Requirements

- Completed application form

- Photographs, maps, sketches, detailed plat, topographic maps and/or other descriptive data, as appropriate

- Statement of justification supporting the reasonableness and practicality of the use

- Information on any water storage facilities and capabilities and any reuse and conservation practices

- Contingency plan (surface water)

- Test data (ground water)

- Other

4. Procedures for Obtaining Permit or Approval

- Applicant submits application to MDNR Regional Hydrologist who reviews application for consistency with criteria set forth in rules

- The Commissioner, MDNR Director, or Regional Hydrologist, as appropriate, makes decision on permit

- Public hearing may be held under various authorities either before or after the decision, if requested

5. Operations Requirements

- Permittee must comply with all terms and conditions set forth in the permit

- File annual pumping report

6. Fees

- Annual report - $\$ 5$

- Application filing - $\$ 15$

- Inspection (surface water only) - $\$ 25$ 
CHAPTER 5.2 (concluded)

\section{Appeal Process}

- An applicant, city, watershed district, or soil and water conservation district may request a hearing within 30 days of the permit decision

E. ADMINISTERING AGENCY:

Director

Division of Waters

Minnesota Department of Natural Resources

Box 32, Centennial Building

658 Cedar Street

Saint Paul, Minnesota 55155

(612) $296-4810$ 
PERMIT FOR DISPLACEMENT OF UNDERGROUND WATERS BY UNDERGROUND STORAGE

OF GAS OR LIQUID UNDER PRESSURE AND/OR STORAGE OF GAS

OR LIQUID UNDERGROUND IN NATURAL FORMATIONS

\section{INTRODUCTION}

The Division of Waters, within the Minnesota Department of Natural Resources (MDNR), has responsibility for issuing permits for underground storage of gas or liquid, under the authority of Minnesota Statutes, Chapter 84. A permit must be obtained from MDNR for any underground storage of gas or liquid under pressure which displaces any underground water or which utilizes natural underground formations.

A. NAME OF PERMIT OR APPROVAL:

- Displacement of Underground Waters by Underground Storage of Gas or Liquid Under Pressure and/or Storage of Gas or Liquid Underground in Natural Formations (S)

B. STATUTORY AUTHORITY:

- Minnesota Statutes, Sections 84.57 through 84.621

C. TITLE OF REGULATION:

- None

D. SUMMARY OF PERMIT/APPROVAL PROCESS:

1. Applicability

- Any proposal to displace underground waters of the State by the storage of gas or liquid under pressure or by utilizing natural underground formations

2. General Requirements

- The proposed storage must be in geological formations lying at least 500 feet below the surface of the soil

- The proposed storage must not impair or pollute any water resources 
- The proposed storage will serve the convenience and necessity of a substantial portion of the gas consuming public

- Private property and individual rights and public resources must be reasonably protected

3. Submission Requirements

- Maps

- Plans

- Specifications describing the proposal

- Other data as the commissioner may require

4. Procedures for Obtaining Permit or Approval

- Applicant submits written application to MDNR Commissioner

- Hearing is held and findings, conclusions, and orders are issued by the commissioner

- Both the notice of hearings and the notice of findings must be published 2 successive weeks in a legal newspaper in the county affected

- Final decision by commissioner

5. Operations Requirements

- Permittee must comply with all terms and conditions of the permit and may be required to demonstrate that he has provided a method to ensure payment of any damage resulting from the operation

6. Fees

- Based on a percentage of the project cost

7. Appeal Process

- Appear of the commissioner's decision must be made to the district court 
CHAPTER 5.3 (concluded)

E. ADMINISTERING AGENCY:

Director

Division of Waters

Minnesota Department of Natural Resources

Box 32, Centennial Building

658 Cedar Street

Saint Paul, Minnesota 55155

(612) 296-4810 
CHAPTER 5.4

APPROVAL OF PLANS FOR CONSTRUCTION OR ALTERATION OF PUBLIC WATER SUPPLIES

INTRODUCTION

The Water Supply and General Engineering Section, within the Minnesota Department of Health $(\mathrm{MDH})$, has responsibility for approval of plans for construction or alteration of public water supplies, under the authority of Minnesota Statutes, Chapter 144. The purpose of this approval is to ensure that plans for public water supply facilities or their alteration meet with State regulations and requirements.

A. NAME OF PERMIT OR APPROVAL:

- Approval of Plans for Public Water Supply Construction or Alteration $(S)$

B. STATUTORY AUTHORITY:

- Minnesota Statutes 1980, Sections 144.12 and 144.383

C. TITLE OF REGULATION:

- Minnesota Code of Agency Rules, Title 7, Section 1.136S

D. SUMMARY OF PERMIT/APPROVAL PROCESS:

1. Applicability

- No construction or alteration of a public water supply shall be made except in accordance with plans and specifications submitted to and approved by the Commissioner of Health

2. General Requirements

- No prescribed form is required

- Plans for all projects supported with public funds must be prepared by a registered professional engineer

3. Submission Requirements

- Plans and specifications as prescribed in Tens' State's Standards 
4. Procedures for Obtaining Permit or Approval

- Applicant submits plans and specifications to MDH

- Once plans and specifications are received, they are reviewed by the MDH staff and approved as submitted or approval is conditional upon the making of prescribed modifications

- No formal procedures or time schedules exist

- Review takes an average of 3 weeks and is based upon Tens States Standards, Well Code, and Rules Relating to Public Water Supplies

5. Operations Requirements

- Construction or alteration can proceed only in accordance with plans as approved

- A community public water supply must be operated by a person certified by the State according to State laws and rules

6. Fees

- None

7. Appeal Process

- None has been established, although one could invoke the contested case hearing procedures contained in the Administrative Procedures Act, Minnesota Statutes, Section 15.0418 (1980)

E. ADMINISTERING AGENCY:

Chief

Water Supply and General Engineering Section

Minnesota Department of Health

717 Delaware Street, Southeast

Minneapolis, Minnesota 55440

(612) 296-5330 
CHAPTER 5.5

WATER WELL CONTRACTOR'S LICENSE

\section{INTRODUCT ION}

The Water Supply and General Engineering Section, within the Minnesota Department of Health (MDH), has responsibility for issuing licenses for water we11 contractors, under the authority of Minnesota Statutes, Chapter 156A. A person who seeks to construct, repair, or abandon water wells for compensation must obtain such a license.

A. NAME OF PERMIT OR APPROVAL:

- Minnesota Water Well Contractor's License (S)

B. STATUTORY AUTHORITY:

- Minnesota Statutes, Chapter 156A (1980), as amended by Laws of 1981, Chapter 278, Sections 2 through 14, and Chapter 179, Section 1

C. TITLE OF REGULATION:

- Minnesota Code of Agency Rules, Title 7, Sections 1.210 through 1.224

D. SUMMARY OF PERMIT/APPROVAL PROCESS:

1. Applicability

- Construction, repair, or abandonment of water wells greater than 25 feet deep regardless of intended use

- Certain individuals who drill monitoring wells are exempt

2. General Requirements

- The applicant must possess the necessary qualifications prescribed in rules, take and pass an examination on the State well code, and pay required fees

- License is renewed annually

- License may be revoked 
CHAPTER 5.5 (continued)

3. Submission Requirements

- Information regarding the application

- Personar information

- Qualifications and experience of the representative designated by the applicant

4. Procedures for Obtaining Permit or Approval

- Applicant submits completed application form to MDH for review

- If the application is complete, an examination on relevant portions of the rule is given by the MDH staff

- Applicant may be interviewed by an advisory council which al so reviews the application and then makes a recommendation to the Commissioner of Health as to whether a license should be issued

- No prescribed time limits for processing the application

5. Operations Requirements

- The license must comply with the licensing statutes and rules cited in items B and C of Chapter 5.5

6. Fees

- Application - $\$ 50$

- Annuar license - $\$ 50$

7. Appeal Process

- The Minnesota Administrative Procedures Act provides for the requesting of a contested case hearing (Minnesota Statutes, Section $15.0418(1980))$ 
CHAPTER 5.5 (concluded)

E. ADMINISTERING AGENCY:

Chief

Water Supply and General Engineering Section

Minnesota Department of Heaith

717 Delaware Street, Southeast

Minneapolis, Minnesota 55440

(612) 296-5330 


\section{LICENSE FOR LIFE-SUPPORT TRANSPORTATION SERVICES}

\section{INTRODUCT ION}

The Division of Health Systems, Emergency Medical Services Section, within the Minnesota Department of Health (MDH), has responsibility for issuing licenses for life-support transportation services, under the authority of the Life Support Transportation Law. The purpose of this 1 icense is to ensure that life-support transportation services meet requirements set forth in the Life Support Transportation Law.

A. NAME OF PERMIT OR APPROVAL:

- License for Life Support Transportation Services (S)

B. STATUTORY AUTHORITY:

- Minnesota Statutes, Section 144.801

C. TITLE OF REGULATION:

- Minnesota Code of Agency Rules, Title 7, Sections 1.601 through 1.611

D. SUMMARY OF PERMIT/APPROVAL PROCESS:

1. Applicability

- Provision or offer of 1ife-support transportation (by 1 and or air ambulance)

2. General Requirements

- Applicant must comply with operating standards regarding personnel, vehicles, equipment, communications, and designated primary service area

- Waivers and variances may be granted but are time-limited

3. Submission Requirements

New applications must demonstrate need based on statutory considerations

- All applicants must submit descriptive data listing area served, fiscal profile, personnel, vehicles, etc. 
4. Procedures for Obtaining Permit or Approval

- Applicant submits application to MDH, Commissioner

- Public hearing are held and recommendations are made by health systems agency(s)

- Within 30 days after receiving recommendation, the commissioner grants or denies license

5. Operations Requirements

- Full compliance or approval of waiver or variance

6. Fees

- $\quad \$ 48$ base fee plus $\$ 24$ per ambulance (currently revising rules for fee schedule)

7. Appeal Process

- Judicial review for commissioner's determinations

E. ADMINISTERING AGENCY:

Section Chief

Emergency Medical Services Section

Division of Health Systems

Minnesota Department of Health

717 Delaware Street, Southeast

Minneapolis, Minnesota 55440

(612) 296-5281 
CHAPTER 5.7

PERMIT FOR THE CONSTRUCTION OR OPERATION OF A HAZARDOUS WASTE FACILITY

INTRODUCTION

The Division of Solid and Hazardous Waste, within the Minnesota Pollution Control Agency (MPCA), has responsibility for issuing permits for the construction or operation of hazardous-waste facilities, under the authority of Minnesota Statutes, Chapter 116. The purpose of this permit is to ensure proper handling of hazardous waste within the State.

A. NAME OF PERMIT OR APPROVAL:

- Permit for the Construction or Operation of a Hazardous Waste Facility (S)

B. STATUTORY AUTHORITY:

- Minnesota Statutes, Section 116.07

C. TITLE OF REGULATION:

- Minnesota Code of Agency Rules, Title 6, Sections 4.9001 through 4.9009

D. SUMMARY OF PERMIT/APPROVAL PROCESS:

1. Applicability

- Hazardous-waste storage, treatment, transfer, and disposal

2. General Requirements

- This permit must be obtained prior to the construction or operation of a hazardous-waste facility

- Special conditions do exist in the permit for facility adequacy

3. Submission Requirements

- Specific information requirements are listed in the rules for each type of facility 
CHAPTER 5.7 (continued)

- Generaliy the information should include

- Waste type

- $\quad$ Site location

- $\quad$ Cost estimate

- Engineering report

- Operation

- Plans and specifications

- An operation manual which includes inventory procedures, inspection and maintenance, operation, closure, long-term monitoring, and financial arrangements

4. Procedures for Obtaining Permit or Approval

- Applicant submits application to MPCA

- Final review and decision by MPCA

- Total estimated processing time is variable

5. Operations Requirements

- Applicant must comply with all applicable rules and regulations and any stipulations set forth in the permit

6. Fees

- None required for State permit

- Counties require licensing fees

7. Appeal Process

- Public notice process involves the opportunity for concerned citizens or groups to interact in the approval or denial of the permit 
CHAPTER 5.7 (concluded)

E. ADMINISTERING AGENCY:

State Agency:

Executive Director

Division of Solid and Hazardous Waste

Minnesota Pollution Control Agency

1935 West County Road, B2

Roseville, Minnesota 55113

(612) $297-2722$

Federal Agency:

Waste Management Section

U.S. Environmental Protection Agency, Region V

111 West Jackson Boulevard

Chicago, Illinois 60604

(312) $353-2197$ or (312) $886-6140$ 
CHAPTER 5.8

PERMIT FOR CONSTRUCTION OR OPERATION OF A SOLID-WASTE-DISPOSAL FACILITY

INTRODUCT ION

The Division of Solid and Hazardous Waste, within the Minnesota Pollution Control Agency (MPCA), has responsibility for issuing permits for the construction or operation of solid-waste-disposal facilities, under the authority of Minnesota Statutes, Chapter 116. The purpose of this permit is to ensure proper handling of solid waste within the State.

A. NAME OF PERMIT OR APPROVAL:

- Permit for Construction or Operation of a Solid Waste Disposal Facility (S)

B. STATUTORY AUTHORITY:

- Minnesota Statutes, Sections 116.07 and 116.081

C. TITLE OF REGULATION:

- Minnesota Code of Agency Rules for Solid Waste, Title 6, Chapter

5, Sections 4.6001 through 4.6012

D. SUMMARY OF PERMIT/APPROVAL PROCESS:

1. Applicability

- Solid-waste storage, treatment, transfer, and disposal

2. General Requirements

- This permit must be obtained prior to construction of any solid-waste storage, treatment, transfer, and/or disposal facility

- An environmental assessment or an environmental impact statements may be required

- Special conditions may be included in permit 
3. Submission Requirements

- Permit application, plans and specifications, and related supporting information, including location, construction, and operation

4. Procedures for Obtaining Permit or Approval

- Applicant submits application to MPCA

- 30-day public notice

- Requests for public hearings are considered by MPCA Board

- Totar estimated processing time, 3 months - 2 years

5. Operations Requirements

- Applicant must comply with all applicable rules and regulations and any stipulations set forth in the permit

6. Fees

- None

7. Appeal Process

- A public hearing may be requested in response to a public notice

E. ADMINISTERING AGENCY:

Director

Division of Solid and Hazardous Waste

Minnesota Pollution Control Agency

1935 West County Road, B2

Roseville, Minnesota 55113

(612) 297-2735 
CHAPTER 5.9

\section{AIR QUALITY INSTALLATION PERMIT}

INTRODUCTION

The Division of Air Quality, within the Minnesota Pollution Control Agency (MPCA), has responsibility for issuing air quality installation permits, under the authority of Minnesota Statutes, Chapter 116. The purpose of this permit is to ensure proper installation of facilities to prevent air pollution.

A. NAME OF PERMIT OR APPROVAL:

- Air Quality Installation Permit (S)

B. STATUTORY AUTHORITY:

- Minnesota Statutes, Section 116.07

C. TITLE OF REGULATION:

- Minnesota Code of Agency Rules for Air Pollution Control, Title 6, Chapters 1 through 32

D. SUMMARY OF PERMIT/APPROVAL PROCESS:

1. Applicability

- Air-emission facilities, air-pollution-control equipment and potential air-contaminant-storage facilities

2. General Requirements

- MPCA has been delegated the responsibility to administer the Federal Prevention of Significant Deterioration (PSD) program

- An environmental assessment or an environmental impact statement may be required pursuant to Environmental Quality Board Rules

3. Submission Requirements

- Composition of effluent stream, before and after control equipment, including emission rate, concentration, temperature, and volume 
- Plans and specifications of emission facility and/or control equipment

4. Procedures for Obtaining Permit or Approval

- Applicant submits application to MPCA, Division of Air Quality

- MPCA reviews application for completeness and compliance with Minnesota Rules, and Federal PSD or non-attainment reviews where applicable

- Public notice required on major installations

- Total estimated processing time, 1 - 6 months

5. Operations Requirements

- Applicant must comply with all applicable rules and regulations and any stipulations set forth in the permit

6. Fees

- None

7. Appeal Process

- Any party may appeal a decision to the MPCA Board, the Minnesota Environmental Council, or the State district court

- Permittee may appeal to MPCA Board

- MPCA Board has option to hold a public hearing

- MPCA Board acts on permit

- Permittee has option to file in State district court for judicial review

E. ADMINISTERING AGENCY:

Chief

Program Development and Air Analysis Section

Division of Air Quality

Minnesota Pollution Control Agency

1935 West County Road, B2

Roseville, Minnesota 55113

(612) 296-7265 
CHAPTER 5.10

AIR QUALITY OPERATING PERMIT

\section{INTRODUCTION}

The Division of Air Quality, within the Minnesota Pollution Control Agency (MPCA), has responsibility for issuing air quality operating permits, under the authority of Minnesota Statutes, Chapter 116. The purpose of this permit is to ensure proper operation of facilities to prevent air pollution.

A. NAME OF PERMIT OR APPROVAL:

- Air Quality Operating Permit (S)

B. STATUTORY AUTHORITY:

- Minnesota Statutes, Section 116.07

C. TITLE OF REGULATION:

- Minnesota Code of Agency Rules for Air Pollution Control, Tit1e 6, Chapters 1 through 32

D. SUMMARY DF PERMIT/APPROVAL PROCESS:

1. Applicability

- Air-emission facilities, air-pollution-control equipment, and potential-air-contaminant-storage facilities

2. General Requirements

- Applicant must obtain this permit prior to operating any air pollution facilities or equipment

3. Submission Requirements

- Composition of effluent stream, before and after control equipment, including emission rate, concentration, temperature, and volume

- Plans and specifications of emission facility and/or control equipment 
4. Procedures for Obtaining Permit or Approval

- Applicant submits application to MPCA, Division of Air Quality

- MPCA reviews application for compliance with MPCA rules

- MPCA has the option to publish public notice or to hold public hearing

- Decision to issue or deny permit is made by MPCA Board or for delegated facilities, by the MPCA staff

- Total estimated processing time, 1 - 8 months

5. Operations Requirements

- Compliance with MPCA rules and USEPA regulations for permit conditions

6. Fees

- None

7. Appeal Process

- Any party may appeal a decision to the MPCA Board, the Minnesota Environmental Council, or the State district court

- Permittee may appeal to MPCA Board

- MPCA Board has option to hold a public hearing

- MPCA Board acts on permit

- Permittee has option to file in State district court for judicial review

E. ADMINISTERING AGENCY:

Chief

Regulatory Compliance Section

Division of Air Quality

Minnesota Pollution Control Agency

1935 West County Road, B2

Roseville, Minnesota 55113

(612) 296-7371 


\section{INTRODUCTION}

The Division of Air Quality, within the Minnesota Pollution Control Agency (MPCA), has responsibility for issuing indirect source permits, under the authority of Minnesota Statutes, Chapter 116. The purpose of this permit is to regulate the quality of the air.

A. NAME OF PERMIT OR APPROVAL:

- Indirect Source Permit (S)

B. STATUTORY AUTHORITY:

- Minnesota Statutes, Section 116.07

C. TITLE OF REGULATION:

- Minnesota Code of Agency Rules for Air Pol1ution Contro1, Tit1e 6, Chapters 1 through 32

D. SUMMARY OF PERMIT/APPROVAL PROCESS:

1. Applicability

- Installations which may affect mobile pollution sources activity, such as major highways, shopping centers, and airports

2. General Requirements

- An environmental assessment or an environmental impact statement may be required pursuant to Environmental Quality Board Rules

3. Submission Requirements

- Name and address of app1icant

- Map showing the location of the site and topography

- Description of proposed use of site 
4. Procedures for Obtaining Permit or Approval

- Applicant submits application to MPCA, Division of Air Quality

- MPCA reviews application for completness and compliance with Minnesota Rule, PCA 19

- Public notice on major or controversial actions

- Total estimated processing time, 1 - 6 months

5. Operations Requirements

- Applicant must comply with all applicable rules and regulations and any stipulations set forth in the permit

6. $\quad$ Fees

- None

7. Appeal Process

- Any party may appeal a decision to the MPCA Board, the Minnesota Environmental Council, or the State district court

- Permittee may appeal to MPCA Board

- $\quad$ MPCA Board has option to hold a public hearing

- MPCA Board acts on permit

- Permittee has option to file in State district court for judicial review

E. ADMINISTERING AGENCY:

Chief

Program Development and Air Analysis Section

Division of Air Quality

Minnesota Pollution Control Agency

1935 West County Road, B2

Roseville, Minnesota 55113

(612) $296-7265$ 
CHAPTER 5.12

OPEN BURNING PERMIT

\section{INTRODUCTION}

The Division of Air Quality, within the Minnesota Pollution Control Agency (MPCA), has responsibility for issuing open burning permits, under the authority of Minnesota Statutes, Chapter 116. The purpose of this permit is to control air pollution caused by open burning.

A. NAME OF PERMIT OR APPROVAL:

- Open Burning Permit (S)

B. STATUTORY AUTHORITY:

- Minnesota Statutes, Section 116.07

C. TITLE OF REGULATION:

- Minnesota Code of Agency Rules for Air Pollution Control, Title 6, Chapters 1 through 32 (Chapter 8)

D. SUMMARY OF PERMIT/APPROVAL PROCESS:

1. Applicability

- All citizens of the State and corporations intending to conduct open burning activities

2. General Requirements

- Application for permit for open burning form (from most local fire chiefs or fire marshals) must be completed

- Prevailing wind must be away from nearby residences at the time of burning

- Burning shall be conducted as far from roadways as possible

- Location of burning not within 600 feet of occupied residences other than applicants

- Location of burning not within 1 mile of airports or runway 
- $\quad 0 i 1 s$, rubber, and other smoke-producing materials must not be burned

- Prior notice is required to be given to local fire authority before burning

3. Submission Requirements

- Name and address of person requesting permit

- Location of intended burning site to include distance from nearest occupied structures

- Local approval from fire chief or marshal

4. Procedures for Obtaining Permit or Approval

- Applicant submits application to local fire authority

- Local fire authority inspects site and approves or disapproves application

- Fire authority submits the application to MPCA for final approval or disapproval

- Permit or denial is returned to fire authority who then issues permit

- Total estimated processing time, 8 - 10 days

5. Operations Requirements

- Applicant must comply with all applicable rules and regulations and any stimpulations set forth in the permit

6. Fees

- None

7. Appeal Process

- Appeals may be made to the issuing authority either by telephone call or letter

- Any party may appeal a decision to the MPCA Board, the Minnesota Environmental Council, or the State district court

- Permittee may appeal to MPCA Board

- MPCA Board has option to hold a public hearing 


\section{CHAPTER 5.12 (concluded)}

- MPCA Board acts on permit

- Permittee has option to file in State district court for judicial review

E. ADMINISTERING AGENCY:

Enforcement Unit

Division of Air Quality

Minnesota Pollution Control Agency

1935 West County Road, B2

Roseville, Minnesota 55113

(612) 296-7300 
CHAPTER 5.13

DISEASED SHADE TREE OPEN-BURNING SITE PERMIT

\section{INTRODUCTION}

The Division of Air Quality, within the Minnesota Pollution Control Agency (MPCA), has responsibility for issuing diseased shade tree open-burning site permits, under the authority of Minnesota Statutes, Chapter 116. The purpose of this permit is to protect the quality of the air where any open burning of diseased trees occurs.

A. NAME OF PERMIT OR APPROVAL:

- Diseased Shade Tree Open Burning Site Permit (S)

B. STATUTORY AUTHORITY:

- Minnesota Statutes, Section 116.07

C. TITLE OF REGULATION:

- Minnesota Code of Agency Rules for Air Pollution Control, Title 6, Chapters 1 through 32

D. SUMMARY OF PERMIT/APPROVAL PROCESS:

1. Applicability

- Municipalities, some counties, and/or tree removal services - burning diseased trees

2. General Requirements

- Application form is available from most local fire chiefs or fire marshals

- Prevailing wind must be away from nearby residences at the time of burning

- Burning shall be conducted as far from roadways as possible

- Location of burning not within 600 feet of occupied residences other than applicants 
- Location of burning not within 1 mile of airports or runway

- $\quad 0 i l s$, rubbers, and other smoke-producing materials must not be burned

- Prior notice is required to be given to local fire authority before burning

- Diseased elm and oak may be burned at the site

3. Submission Requirements

- Name and address of person requesting permit

- Location of intended burning site to include distance from nearest occupied structures, airport, landfills, and other tree sites

- Local approval from fire chief

4. Procedures for Obtaining Permit or Approval

- Applicant submits application to MPCA

- In Twin Cities - Metropolitan Area, application forms are considered by the Metropolitan Council and Minnesota Department of Agriculture before being processed by the MPCA (any other application is submitted directly to MPCA)

- Site inspections throughout State are conducted prior to permit issuance

- Total estimated processing time, 1 - 2 months

5. Operations Requirements

- Applicant must comply with all applicable rules and regulations and any stipulations set forth in the permit

6. Fees

- None

7. Appeal Process

- Appeals may be made to the issuing authority either by telephone call or letter 
- Any party may appea1 a decision to the MPCA Board, the Minnesota Environmental Council, or the State district court

- Permittee may appeal to MPCA Board

- MPCA Board has option to hold a public hearing

- MPCA Board acts on permit

- Permittee has option to file in State district court for judicial review

E. ADMINISTERING AGENCY:

Enforcement Unit

Division of Air Quality

Minnesota Pollution Control Agency

1935 West County Road, B2

Roseville, Minnesota 55113

(612) $296-7300$ 
INTRODUCTION

The Division of Water Quality, within the Minnesota Pollution Conrol Agency (MPCA), has responsibility for issuing certificates of exemption for use, possession, sale, purchase, or manufacture of polychlorinated biphenyls (PCB), under the authority of Minnesota Statutes, Chapter 116. The purpose of this permit is to protect the health of all persons involved with PCB.

A. NAME OF PERMIT OR APPROVAL:

- Certificate of Exemption for Use, Possession, Sale, Purchase, or Manufacture of Polychlorinated Biphenyls (S)

B. STATUTORY AUTHORITY:

- Minnesota Statutes, Section 116.37

C. TITLE OF REGULATION:

- Minnesota Code of Agency Rules, Title 6, Section 4.8038

D. SUMMARY OF PERMIT/APPROVAL PROCESS:

1. Applicability

- The use, possession, sale, purchase, or manufacture of PCB or products containing PCB

2. General Requirements

- Applicant must demonstrate that PCB is properly used or contained so that $P C B$ will not escape into the environment

3. Submission Requirements

- A listing of all PCB to be used and proposed location

- Information to show that any spills will be contained, recovered, and properly disposed of 
4. Procedures for Obtaining Permit or Approval

- Applicant submits application to MPCA

- MPCA issues certificate of exemption where there are no outstanding hearing requests

- Certificate of exemption is public noticed for 30 days

5. Operations Requirements

- Permittee must comply with all rules and regulations which govern the use, storage, disposal, and recovery of PCB set forth by the State

6. Fees

- None

7. Appeal Process

- A contested case hearing may be held

E. ADMINISTERING AGENCY:

Chief

Permits Section

Division of Water Quality

Minnesota Pollution Control Agency

1935 West County Road, B2

Roseville, Minnesota 55113

(612) $296-7221$ 


\section{INTRODUCT ION}

The Division of Water Quality, within the Minnesota Pollution Control Agency (MPCA), has responsibility for issuing liquid storage site permits, under the authority of Minnesota Statutes, Chapter 115. The purpose of this permit is prevent water pollution which may be caused by storage of certain Tiquids.

A. NAME OF PERMIT OR APPROVAL:

- Permit for Liquid Storage Site for Storage of $0 i 1$ or Other Liquid Capable of Polluting Waters of the State (S)

B. STATUTORY AUTHORITY:

- Minnesota Statutes, Section 115.03

C. TITLE OF REGULATION:

- Minnesota Code of Agency Rules for Water Pollution Control, Title 6, Chapter 4

D. SUMMARY OF PERMIT/APPROVAL PROCESS:

1. Applicability

- Above ground storage of 1,500 gallons or more of liquids which may cause pollution

2. General Requirements

- Application must file application on MPCA form

- Environmental Assessment Worksheet required for proposed facilities of 1 million gallons or more

3. Submission Requirements

- Plans and specifications for the design and construction of the storage containment structure 
4. Procedures for Obtaining Permit or Approval

- Applicant submits application to MPCA

- For new storage facilities of 50,000 gallons or more, public notice of the proposed permit is published for 30 days in the State Register

- Agency issues permit unless hearing is authorized

- Total estimated processing time, minimum 90 days

5. Operations Requirements

- Applicant must comply with all rules and regulations and any stipulations set forth in the permit which govern the storage of 0 il

6. Fees

- None

7. Appeal Process

- A contested case hearing may be held on a proposed permit

E. ADMINISTERING AGENCY:

Chief

Technical Review Section

Division of Water Quality

Minnesota Pollution Control Agency

1935 West County Road, B2

Roseville, Minnesota 55113

(612) 296-7201 
CHAPTER 5.16

NPDES AND STATE DISPOSAL PERMIT

INTRODUCTION

The Division of Water Quality, within the Minnesota Pollution Control Agency (MPCA), has responsibility for issuing National Pollutant Discharge Elimination System (NPDES) and State disposal permits, under the authority of Minnesota Statutes, Chapter 115. The purpose of this permit is to prevent water pollution as a result of discharge of pollutants into State waters or faulty construction/operation of wastewater disposal systems.

A. NAME OF PERMIT OR APPROVAL:

- National Pollutant Discharge Elimination System and State Disposal Permit (S)

B. STATUTORY AUTHORITY:

- Minnesota Statutes, Sections 115.03 and 115.07

C. TITLE OF REGULATION:

- Minnesota Code of Agency Rules for Water Pollution Control, Title 6 , Sections $4.8014,4.8015,4.8024,4.8025$, and 4.8036

D. SUMMARY OF PERMIT/APPROVAL PROCESS:

1. Applicability

- The construction and operation of a wastewater disposal system and/or the discharge of pollutants into waters of the State

2. General Requirements

- A complete application and any additional technical information must be submitted before a permit can be processed

- A permit must be obtained prior to commencement of a new discharge or new construction 
3. Submission Requirements

- Treatment system construction - plans and specifications which demonstrate that the treatment system will conform to agency requirements and that treated wastewaters will comply with applicable State and Federal effluent and water-quality standards

- Effluent - quantitative and qualitative analyses

4. Procedures for Obtaining Permit or Approval

- Applicant submits application to MPCA 180 days prior to commencement of activity

- MPCA drafts permit and issues public notice for 30 days

- MPCA considers public comment and issues permit after resolution of any outstanding hearing requests

- Totar estimated processing time, 90 days (uncontested)

5. Operations Requirements

- Domestic wastewater treatment plant operators must receive State certification

6. Fees

- None

7. Appeal Process

- Contested case hearing may be requested by any person and authorized on a proposed permit

- Hearing conducted before Hearings Examiner of State Hearings Examiners Office

- Hearings Examiner produces findings of fact and recommendations which are presented to MPCA Board for final decision 
CHAPTER 5.16 (concluded)

E. ADMINISTER ING AGENCY:

Chief

Permits Section

Division of Water Quality

Minnesota Pollution Control Agency

1935 West County Road, B2

Roseville, Minnesota 55113

(612) 296-7221 


\section{INTRODUCTION}

The Division of Water Quality, within the Minnesota Pollution Control Agency (MPCA), has responsibility for issuing State certification for permits under the 1977 Clean Water Act, under the authority of Minnesota Statutes, Chapter 115. The purpose of this permit is to ensure that permits issued by the Federal government will comply with State water-quality standards.

A. NAME OF PERMIT OR APPROVAL:

- State Certification for Federal Permits Under the 1977 Clean Water Act $(S)$

B. STATUTORY AUTHORITY:

- Minnesota Statutes, Sections 115.03 and 115.07

C. TITLE OF REGULATION:

- Minnesota Code of Agency Rules for Water Pollution Control, Title 6, Chapter 36

D. SUMMARY OF PERMIT/APPROVAL PROCESS:

1. Applicability

- State certification of Federal licenses for discharges to surface waters

2. General Requirements

- Applicant must obtain 401 Certification for dredging or filling prior to discharging into State surface waters

3. Submission Requirements

- Plans and specifications for any treatment facility construction

- Effluent and receiving-water-quality data may be required 
4. Procedures for Obtaining Permit or Approval

- Application submits application to MPCA

- Public notice (401 Certification) for 30 days

- Agency issues certification where there are no outstanding hearing requests

5. Operations Requirements

- Applicant must comply with State effluent and water-quality standards

6. Fees

- None

7. Appeal Process

- A contested case hearing may be held

E. ADMINISTER ING AGENCY:

Chief

Permits Section

Division of Water Quality

Minnesota Pollution Control Agency

1935 West County Road, B2

Roseville, Minnesota 55113

(612) 296-7221 
CHAPTER 5.18

\section{NOISE REGULATIONS}

No regulations, permits, or approvals exist for State regulation of noise in the State of Minnesota at this time. Noise may be regulated on the local government level in the State. Local government agencies may be contacted for information related to noise regulations. 
SECTION 6.0

SOCIAL/ECOLOGICAL PRESERVATION

$130 a$ 
CHAPTER 6.1

\section{WILDL IFE COLLECTION PERMITS}

Fieldwork is necessary in the preparation of Environmental Assessments and Environmental Impact Statements which require wildlife collection permits from the State. These may be obtained from:

Division of Fish and Wildiife

Minnesota Department of Natural Resources

Box 33, Centennial Office Building

658 Cedar Street

Saint Paul, Minnesota 55155

Phone: (612) 296-2894 


\title{
CHAPTER 6.2
}

\section{HISTORICAL PRESERVATION}

Historical and prehistorical resources should be addressed within environmental assessments and environmental impact statements. Development of lands which contain historical or prehistorical resources is subject to approval by the Minnesota Historical Society. Information may be obtained from:

\author{
Minnesota Historical Society \\ 690 Cedar Street \\ Saint Pau1, Minnesota 55101 \\ Phone: (612) 726-1171
}


SECTION 7.0

LOCAL REGULATORY POLICY

$132 a$ 


\section{LOCAL GOVERNMENT LAND USE AND NATURAL RESOURCE CONTROL ENABL ING LAWS}

Zoning and subdivision powers are currently regulated by the local governments in Minnesota, including townships, counties, municipalities, and cities. These powers are regulated by the following:

\section{- Extra Territorial Zoning and Subdivision Powers}

According to current enabling legislation (Minnesota Statutes, Section 462.357), a municipality may extend its subdivision controls 2 miles beyond its boundaries, even if the county has its own subdivision controls. Under current law, the only time a city is prevented from extending its subdivision authority into the 2-mile area is when an adjacent urban town (a township having more than 1,200 people living in platted areas that receives authority to plan and zone from the Municipal Planning Act, Section 462.357) has adopted subdivision controls. The city cannot extend its zoning regulations into the 2 -mile area if either the county or the township has adopted zoning controls.

While the city can control the pattern of development through subdivision regulations, it may not have control over the type or density of development that takes place. Since development occurring in this 2-mile area will likely become part of the city someday, it seems reasonable to provide the city with authority to make or participate in the orderly development of this area.

\section{- Conditionar Use Permits}

The County Planning Act (Minnesota Statutes, Section 394.301) was revised in 1974 to require establishment of standards and criteria in the zoning ordinance which must be satisfied before a conditional use is granted. Specifically, the law says, "Such standards and criteria shall include both general requirements for al1 conditional uses and, insofar as practicable, requirements specific to each designated conditonal use." On the other hand, the Municipal Planning Act -- although implying in Minnesota Statutes, Section 462.357, that municipalities have the authority to grant conditional uses -- is silent on the matter of establishing standards and criteria.

By not providing specific standards and criteria, it is not clear to developers or adjacent property owners the conditions under which a conditional use would be allowed. In municipalities, standards and criteria are usually established at the time a developer applies for the conditonal use. This can result in arbitrary and discriminatory decisions by the municipality and makes those decisions subject to litigation. 
CHAPTER 7.1 (continued)

- Regulation of Subdivisions by Municipalities

Chapter 566, of Minnesota Laws, 1980, made changes to the Municipal Planning Act with regard to subdivision regulations. Some of these changes are confusing and are in need of clarification. For example, the amendments now mix zoning and subdivision provisions in a section of law that previously addressed only subdivision regulations (Minnesota Statutes, Section 462.358). Zoning also continues to be addressed in a separate law (Minnesota Statutes, 462.357). Another change to Section 462.358 of the Minnesota Statutes that occurred in 1980, provided for lot size standards in the subdivision regulations. Lot size has traditionally been a function of the zoning ordinance and not subdivision regulations. Zoning districts often require different minimum lot sizes. For example, an R-1 district (single-family residential) may require a 10,000-square-foot minimum while an $R-3$ district (multiple-family residential) may require a 6,000-square-foot minimum. The change results in the application of one minimum lot size to a variety of different zoning districts. Mixing the terminology of subdivision and zoning regulations is confusing and hinders the development of sound and meaningful 1 and use regulations.

The 1980 amendments al so permit the establishment of a joint board to adopt zoning and subdivision regulations for the 2 -mile area outside city boundaries if requested by the county or township. While this appears to be a step in the right direction, there is no provision for the city to request a joint board if the township or the county are developing regulations. Moreover, the compositon of the joint board may be a problem when potentially there could be five or six units of government involved (i.e., townships, cities and counties).

- Township Planning and Zoning

Section 394.33 of the Minnesota Statutes discusses the relationship of counties and townships regarding planning and zoning. Of particular significance is the part pertaining to the adoption of controls, which states: "no town shall enact or enforce official controls inconsistent with or less restrictive than the standards prescribed in the official controls adopted by the board" (county). The problem appears to be with the words "less restrictive than," and what they mean. For example, is a township less restrictive than the county if it zones an area as industrial when the county ordinance has classified the area agricultural or residential? One might agree, yet in a recent district court case involving a situation like the above, the court ruled that the township has the power and authority to plan and zone in whatever manner it chooses, without regard to pre-existing county zoning. Such a ruling clearly points out the 
need for more specificity in the law regarding the county-township relationship. More than ever, it seems to point to the need for a common plan agreed to by all affected governmental units. If other courts come to similiar decisions on this topic, planning, as we know it, could change drastically. 